\title{
LOS ARTÍFICES DE LA LEGISLACIÓN ELECTORAL: UNA APROXIMACIÓN A LA TEORÍA DEL GOBIERNO REPRESENTATIVO EN ESPAÑA $(1845-1870)^{1}$
}

\section{Rafael Zurita, Ma Antonia Peña y María Sierra}

Universidades de Alicante, Huelva y Sevilla, respectivamente

RESUMEN: Partiendo de una perspectiva parcialmente prosopográfica, este artículo tiene como objetivo valorar los postulados esgrimidos por las diversas corrientes políticas españolas acerca del gobierno representativo durante las décadas centrales del siglo XIX. Con la progresiva implantación del liberalismo en España, la discusión sobre la filosofía y los mecanismos de la representación política en la construcción del Estado liberal alcanzó un complejo significado. $Y$, aunque la preocupación intelectual y política en torno a la representación no se materializó, salvo excepciones, en una elaboración teórica como la desplegada en Francia o en Gran Bretaña, es posible analizar, a través de los debates parlamentarios de la legislación electoral, los principales problemas percibidos por los diputados.

Palabras Clave: Representación política. Parlamento. Elecciones. Partidos políticos.

ABSTRACT: This article will study from a prosopographical point of view the differing ideas about representative government offered by the various political strands of mid-19th century Spain. With the progressive implementation of liberalism in Spain, the debate about the philosophy and mechanisms of political representation in the construction of the liberal state reached a critical point. Although there was only occasionally political and intellectual debate along the lines of that of France or Great Britain, it is possible to isolate the issues that concerned deputies by studying parliamentary debates on electoral legislation.

KEY WORDS: Political representation. Parliament. Elections. Political parties. Franchise.

1 Este trabajo se inscribe en un proyecto de investigación sobre la idea de la representación política en la España liberal (1845-1890), del Ministerio de Ciencia y Tecnología con financiación FEDER (BHA2002-01007). 


\section{INTRODUCCIÓN}

Convencidos del complejo significado que tuvo la discusión sobre la filosofía y los mecanismos de la representación política en la construcción del Estado liberal, creemos que resulta de gran interés valorar los postulados esgrimidos por las diversas corrientes políticas en el Parlamento español durante las décadas centrales del siglo XIX. Conviene tener en cuenta, no obstante, que ningún partido fijó explícitamente su concepción sobre la representación y ésta no siempre se trasladó necesariamente a la legislación electoral, por lo que su reconstrucción incluye, junto a algunos trazos bien definidos, no pocas ambigüedades, dudas e, incluso, contradicciones. Esto fue debido, en parte, a la dinámica Gobierno-oposición, pero también respondió a la distinción entre planteamientos teóricos y práctica política, que traslucía los diversos modos de entender la legitimidad del poder y los mecanismos idóneos para la implantación de las instituciones representativas liberales. Con independencia del grado de coherencia ideológica de cada partido y de las diferencias que pudieran observarse en su seno, el análisis de su universo representativo revela los parámetros esenciales en los cuales los políticos de la época enmarcaron su visión sobre el gobierno de los ciudadanos. En esta visión, la formación y la esencia del Parlamento ocuparon un lugar central y, por ello, los discursos desarrollados durante los debates sobre la legislación electoral se articularon en torno a la «independencia» política de electores y elegibles y a la «legitimidad» de los intereses representados.

Para lograr nuestro objetivo hemos acudido a una metodología parcialmente prosopográfica, en el sentido de que, si bien partimos del elemento cuantitativo — una muestra de diputados_-, la cuantificación no domina el análisis. Y esto porque creemos que no es sencillo obtener suficiente información de las fuentes del siglo XIX, muchas de ellas hagiográficas, al tiempo que resulta complicado confeccionar para estos diputados una clasificación satisfactoria, pues ésta siempre se encontrará mediatizada por el criterio empleado por el historiador. Desde luego, la prosopografía, como herramienta para la historia política, se ha mostrado útil para abordar importantes problemas, como son las raíces de la acción política y la estructura y la movilidad sociales; sin embargo, según ha señalado Stone, el análisis prosopográfico puede presentar limitaciones para la comprensión histórica, si se dejan de lado el marco institucional dentro del cual funciona el sistema o las ideas políticas ${ }^{2}$. Por eso, optamos aquí por una biografía colectiva en la que el contexto personal — generacional, pro-

2 STONe, L.: «Prosopografía», en STONE, L.: El pasado y el presente, México, 1986, pp. 61-94. Vid. también: Charle, Ch.; Nagle, J. y Richard, M.: Prosopographie des Élites Francaises, Paris, 1982. Carasa Soto, P. (ed.): Elites. Prosopografía contemporánea, Valladolid, 1994. Burdiel, I. y ROMEO, M.C.: «Los sujetos en el proceso revolucionario español del siglo XIX: el papel de la prosopografía histórica», en Historia Contemporánea (Bilbao) 13-14 (1996), pp. 149-156; CARASA SOTO, P.: «De la burguesía a las elites, entre la ambigüedad y la renovación conceptual», en Ayer (Madrid) 42 (2001), pp. 213-237. 
fesional, académico - de los parlamentarios es empleado para enmarcar el cuadro de uno de los panoramas ideológicos que preocuparon al liberalismo posrevolucionario español ${ }^{3}$.

Partiendo de los debates sobre proyectos y proposiciones de ley electoral que tuvieron lugar entre 1845 y 1870, hemos seleccionado un grupo formado por los ministros que presentaron proyectos de ley, los diputados que integraron las comisiones que informaron estos proyectos o redactaron los proyectos de ley de 1856 y 1870 — las dos normas siguieron este procedimiento por el contexto revolucionario en el que se constituyó el Congreso-, y, por último, los diputados que presentaron proposiciones de ley o enmiendas e intervinieron en su defensa. Disponemos así de un conjunto de 66 diputados que conforman una muestra suficientemente significativa de los políticos que manifestaron interés por el problema de la representación política. Reconstruidas sus trayectorias biográficas ${ }^{4}$, los hemos agrupado en función de su adscripción política

3 Entre los trabajos que utilizan la herramienta prosopográfica para el análisis político, destacamos: BuRdiel, I.: La política de los notables. Moderados y avanzados durante el Régimen del Estatuto Real (1834-36), Valencia, 1987, y CrUZ, J.: Los notables de Madrid. Las bases sociales de la revolución liberal española, Madrid, 2000.

4 Principales fuentes consultadas:

- Diccionarios de parlamentarios: AgirReaZkuenaga, J. y otros: Diccionario de parlamentarios de vasconia (1808-1876), Vitoria, 1993. CARASA SOTO, P. (Dir.): Elites castellanas de la Restauración, 2 vols, Valladolid, 1997. Barreiro FernándeZ, X.R. (Dir.): Parlamentarios de Galicia, biografías de deputados e senadores (1810-2001), A Coruña, 2002. PaniaguA, J. y PiQueras, J.A. (dirs.): Diccionario biográfico de políticos valencianos, 1810-2003, Valencia, 2003. GARRIDO, A. (Dir.): Diccionario biográfico de los parlamentarios de Cantabria (1902-2002), Santander, 2003.

- Ficheros de diputados de la Biblioteca y del Archivo del Congreso de los Diputados; Diccionario Enciclopédico Espasa-Calpe; Catálogo del Patrimonio Bibliográfico español del siglo XIX (http://www.mcu.es/ccpb/); Expedientes personales de los senadores (http://www.senado.es); página de José Ramón Urquijo Goitia sobre los Ministros españoles (http://www.ih.csic.es/lineas/jrug/ diccionario/ministros); ARAQUe, N.: Las elecciones en el reinado de Isabel II: la Cámara Baja. Tesis de Doctorado inédita (Madrid, Universidad Autónoma, 2004).

- Repertorios biográficos de la época: Asamblea Constituyente de 1854: biografías de todos los diputados y todos los hombres célebres que han tomado parte en el alzamiento nacional, Madrid, 1854-1855; BAUTISTA, M.: Los diputados pintados por sus hechos: colección de estudios biográficos sobre los elegidos por el sufragio universal en las constituyentes de 1869 recopilados por distintos literatos, Madrid, 1869-1870; FERNÁNDEZ De Los Ríos, Á. et. al.: La Asamblea Constituyente de 1869: biografías de todos los representantes de la nación, Madrid, 1869.

— Diversos trabajos monográficos: PRO RUIZ, J.: «Información fiscal agraria, redes clientelares y progresismo: la Estadística de la Riqueza de 1841», en Revista de Investigaciones Sociológicas (Madrid) 45-1 (1987), pp.199-216; RiQUER I PERMANYER, B. de: «Estudi Introductori» a Epistolari polític de Manuel Duran i Bas, Barcelona, 1990, pp. 13-153; VILLACORTA, J.L.: La derrota intelectual del carlismo. Aparici y Guijarro frente al siglo, Bilbao, 1990; BURDIEL, I.: "Análisis prosopográfico y revolución liberal. Los parlamentarios valencianos (1834-1854)», en Revista de Estudios Políticos (Madrid) 93 (1996), pp. 123-138; Ollero VALLES, J.L.: El progresismo como proyecto político en el reinado de Isabel II: Praxedes Mateo Sagasta, 1854-1868, Logroño, 1999; Gómez URDaÑEZ, G.: Salustiano de Olózaga. Elites políticas en el liberalismo español, 1805-1843, Logroño, 2000; Ollero VALLES, J.L.: «Sagasta y el 
predominante: moderada, progresista, unionista, demócrata-republicana y neocatólico-carlista. Somos conscientes de que las fronteras entre unas corrientes y otras no estaban claramente marcadas y que, en más de un caso, un diputado vinculado a un grupo político podía transitar a otro, o esgrimir, coyunturalmente, posiciones no acordes con su definición partidista. En esos casos, hemos insertado al diputado en un determinado partido teniendo en cuenta la posición político-ideológica que presentó en el momento de su intervención más significada en materia electoral 5 .

\section{PERFIL GENERACIONAL, FORMATIVO Y PROFESIONAL DE LOS DIPUTADOS}

Definidas detalladamente por los requisitos que la legislación electoral exigía a la categoría de los elegibles, muchas de las características generales del grupo de diputados encargado de su elaboración o discusión no vienen sino a poner de relieve el concepto ideal de parlamentario predominante en la sociedad de esta época ${ }^{6}$. Salvo la procedencia o naturaleza del diputado, aspectos como su formación académica, su profesión o su pertenencia a una determinada generación política aparecen, directa o indirectamente, condicionados por lo estipulado en los distintos marcos constitucionales y legislativos que se sucedieron entre 1844 y 1876. Así, generacionalmente, los diputados del grupo estudiado hubieron de cumplir los 25 años antes de poder postularse como candidatos electorales y, en su mayor parte, obtuvieron su primer escaño en el Congreso con edades comprendidas entre los 30 y los 40 años. Hablamos de casi la mitad de la muestra —el 46,9\%—, porcentaje que se incrementa significativamente hasta el $65,2 \%$ si alargamos esta variable hasta los 45 años ${ }^{7}$.

liberalismo progresista: de la revolución al fusionismo del turno» en CAPELLAN DE Miguel, G. (Ed.): Parlamento y parlamentarismo en la España liberal. Manuel de Orovio y Práxedes Mateo-Sagasta, Logroño, 2000, pp.179-230; VAllejo I. y OJEDA, P.: «Pedro Calvo Asensio (1821-1863): 'la esperanza de un partido'», en SERRANO GARCÍA, R. (Ed.): España, 1868-1874. Nuevos enfoques sobre el Sexenio Democrático, Valladolid, 2002. pp.15-30; Sosa WAGNER, F.: José Posada Herrera. Veinticinco discursos y un prólogo, Oviedo, 2002; SERRANO GARCÍA, R.: "Aproximación a Tomás Rodríguez Pinilla (1815-1886): demócrata e intelectual salmantino», en Los orígenes del liberalismo, (edición en CDROM del Congreso de los Diputados), Madrid, 2002; Romeo MATEO, $M^{\mathrm{a}}$.C.: «Política católica para después de la revolución o las vías del antiliberalismo: Aparisi y Guijarro, 1843-1844», en Trienio (Madrid) 41 (2003), pp. 133-162; Pan-Montojo, J.: «Pascual Madoz e Ibáñez: perfil de un progresista isabelino", en MARtín ACEÑA, P. y VAllejo PousadA, R.: La Hacienda desde sus minutos. El siglo XIX, Zaragoza, 2006 (en prensa).

5 Por ejemplo, Cándido Nocedal, en su calidad de ministro moderado en 1857 o José Polo de Bernabé, como unionista durante la década de 1860.

6 PeÑa, M.A.; Sierra, M. y Zurita, R.: «Elegidos y elegibles. La construcción teórica de la representación parlamentaria en la España isabelina (1844-1868)», en Revista de Historia das Ideias (2006) (en prensa).

7 Estas cifras vienen a corroborar otras similares proporcionadas por estudios prosopográficos referidos a otros colectivos en la misma época. En este sentido, Urquijo sitúa en un 42,2\% el por- 
Aunque no hay que perder de vista que la percepción social de conceptos como «edad» y «juventud» a lo largo del siglo XIX era sensiblemente distinta a la nuestra debido a obvios motivos culturales y demográficos, estos números demuelen la apresurada impresión de que el parlamentarismo español estuvo en aquellos años en manos de individuos vetustos. El tópico parece romperse en este punto y nos devuelve la imagen de un hemiciclo mucho más joven o, lo que es más certero, de un hemiciclo en el que la participación activa en los debates - al menos es el caso de los que atañen a la legislación electoral— está en manos de individuos más jóvenes de lo que a priori podría pensarse. De hecho, en el caso concreto de la elaboración de las leyes electorales, podemos apreciar que la intervención del diputado en las discusiones también se desarrolló de manera muy temprana, si bien, como tendremos la oportunidad de observar en lo sucesivo, experiencia política y juventud no fueron necesariamente términos antónimos. En algunos casos, el diputado novel se incorpora activamente a la dialéctica parlamentaria casi al mismo tiempo de obtener su primera credencial, aunque lo normal es que la media del grupo oscile entre los $40 \mathrm{y}$ 44 años $(24,2 \%)$ y los 45 y $49(21,2 \%)$. Por encima de esta edad, es decir, con más de 50 años a sus espaldas, sólo hemos podido identificar a 9 diputados, entre los que se encontraban algunos líderes históricos como el progresista Evaristo San Miguel.

A primera vista, estas cifras escuetas parecen señalar que el grupo que exhibió mayor dinamismo ante las cuestiones electorales fue un grupo relativamente joven y sujeto a una importante renovación generacional con respecto a los diputados que ocuparon sus escaños entre 1820 y 1844 . En este sentido, el análisis de las continuidades de su vida parlamentaria resulta especialmente esclarecedor. De los 66 diputados estudiados, el grupo más numeroso -24 diputados $(36,4 \%)$ - fue aquél que sólo tuvo presencia parlamentaria durante la etapa isabelina, sin que hayan podido documentarse otras apariciones políticas en las Cortes de etapas posteriores. A continuación, habría que mencionar un conjunto de 13 diputados isabelinos $(19,7 \%)$ que renovaron sus escaños en algún momento del Sexenio y a 12 diputados $(18,2 \%)$ que, incluso, alargaron su representación política hasta la Restauración. Ante la evidencia de estas cifras, no parece que pueda afirmarse que el Sexenio constituyese un corte radical en la vida política española, pero sí que para una buena parte del grupo analizado supuso la ruptura de trayectorias políticas personales iniciadas con ante-

centaje de parlamentarios vascos que tenían entre 30 y 45 años en el período comprendido entre 1808 y 1876; para las constituyentes de 1854, Casanova indica que el 67,7\% de los diputados se encontraba entre los 31 y 50 años; finalmente, Fuente evalúa en un 53,5\% el número de diputados de 1869 que tenía de 36 a 50 años. URQUijo Goitia, J.R.: "Análisis prosopográfico de los parlamentarios de Vasconia (1808-1876)», en Revista de Estudios Políticos (Madrid) 93 (1996), pp. 97121, p. 118; CASANOVA AGUilaR, I.: «Las Constituyentes de 1854: origen y fisonomía general», en Hispania (Madrid) 37 (1984), pp. 135-172, p. 153; y FUENTE MONGE, G. de la: Los revolucionarios de 1868, Madrid, 2000, p. 227. 
rioridad. En este mismo plano, resulta muy significativo que sólo 11 diputados $(16,7 \%)$ de los que habían ocupado sus escaños durante el reinado de Isabel II retomasen en la Restauración una carrera política que, sin embargo, los mantuvo separados del Congreso entre 1868 y 1876 . Este fue el caso, por ejemplo, del diputado Polo de Bernabé, sin duda uno de los políticos e intelectuales más activos en el campo de la gestación de las leyes electorales. Aunque circunscrita al grupo de diputados seleccionado para este estudio, la tesis de la continuidad generacional a lo largo del extenso período comprendido entre 1846 y 1890 que han sostenido autores como Linz o Fuente debe ser matizada ${ }^{8}$, al menos, enunciada con suma prudencia, pues, en el conjunto que hemos analizado, tan sólo se advierte, y con carácter relativo, en lo que atañe al reclutamiento político de diputados en las Cortes de la Restauración: del global de la muestra, 26 diputados $(39,3 \%)$ prolongaron su actividad parlamentaria más allá de 1876 . Aparte de considerar que, salvo en contextos especialmente rupturistas o revolucionarios, siempre hay que apreciar como normal la existencia de una cierta continuidad, los porcentajes obtenidos en nuestra muestra — que, ni siquiera en el mejor de los casos, alcanzan a la mitad de los diputados- permiten sustentar la tesis de que a lo largo de este período se desarrolló un importante relevo generacional en los escaños del Congreso, que, por otra parte, explicaría, como comprobaremos más adelante, la propia evolución de los marcos electorales y las distintas líneas programáticas sostenidas sucesivamente en este tema por los representantes del Gobierno y de los partidos.

Indirecta pero sustancialmente condicionadas por los requisitos censitarios que primaron en la legislación electoral del siglo XIX español, la formación académica y los perfiles profesionales de esta muestra de diputados nos parecen variables de análisis especialmente explicativas de las realidades sociales y económicas que estuvieron representadas en el parlamentarismo español. Hemos, además, separado ambos aspectos por considerar que, mientras la formación del individuo traduce su preparación y orientación intelectual, su ejercicio profesional — reflejo secundario de ésta — nos habla de modo particular de sus niveles de renta, su ubicación en la jerarquía social o su prestigio y consideración pública. En el primero de los casos, pocas novedades pueden constatarse en este grupo que lo diferencie del panorama sociológico del parlamentarismo español del siglo XIX que han reflejado ya diversos estudios clásicos sobre el tema y que perfectamente documenta Araque en su Tesis Doctoral9. De manera mayorita-

8 Según Linz, el 26\% de los diputados de 1876 había pertenecido también a la Cámara de 1869 y un $22 \%$ lo había sido también entre 1846 y 1874, pero entendemos que ambos porcentajes no pueden sumarse, puesto que uno incluye al otro. LINZ, J.J.: «Continuidad y discontinuidad en la élite política española de la Restauración al régimen actual», en Estudios de Ciencia Política y Sociología (Homenaje a C. Ollero), Madrid, 1972, pp. 365-367. Por su parte, Fuente ha establecido que el 61,4\% de los diputados de 1869 lo había sido también en alguna ocasión entre 1834 y 1868. FUENTE MONGE, G. de la: Op. cit., p. 229.

9 ARAQUe, N.: Op. cit., passim. 
ria, el grupo de los diputados que habían cursado estudios de Derecho se impone sobre el resto, convirtiendo virtualmente al Congreso español en una cámara de abogados: 47 de los 66 diputados que venimos analizando - es decir, un $71,2 \%$ de la muestra - presentaban una formación preferente en el campo jurídico, aunque, a veces, combinada con otros estudios de carácter humanístico. Estos valores, en cualquier caso, no hacen sino corroborar una tradicional vinculación de la política española - y europea - al campo de la jurisprudencia, cuyos orígenes pueden rastrearse desde los primeros años de implantación del régimen liberal y que se proyecta en adelante hasta bien entrado el siglo XX. Naturalmente, para la mentalidad de la clase política decimonónica, era la formación jurídica la que, aparte de proporcionar un prestigio social añadido, mejor preparaba para los rudimentos de la política activa y la que dotaba al político de mejores recursos discursivos y de un conocimiento más directo de las leyes y la práctica administrativa ${ }^{10}$. Por estas mismas razones, no debe extrañar que un tema tan específico como el de la confección de la legislación electoral atrajese particularmente a los políticos relacionados con el mundo del Derecho. Finalmente, excluyendo a 10 diputados de los que no hemos podido conocer su titulación académica — quizás porque nunca culminaron su formación y por eso no consta en los repertorios biográficos consultados-, el resto del grupo se reparte de forma puntual entre perfiles especializados en Historia (Lafuente), Farmacia (Calvo Asensio), Medicina (Cervera), Ingeniería (Sagasta) o Matemáticas (Mencos), que introducen, sin duda, en el Parlamento elementos novedosos. Por encima de ellos, sólo pueden ser destacados tres diputados procedentes de una formación castrense: los militares Escosura, López Domínguez y San Miguel.

De todos modos, como es lógico, la correspondencia entre la formación académica del individuo, por un lado, y su dedicación profesional o sus vías de obtención de ingresos, por otro, dista mucho de ser exacta. Por lo demás, en este punto concreto, la metodología prosopográfica nos desvela una de sus más flagrantes debilidades, pues se hace evidente que en la ordenación de los datos biográficos el análisis cuantitativo está totalmente mediatizado por el criterio clasificatorio utilizado por cada investigador. Así, por ejemplo, a la hora de ordenar la multiplicidad de datos que se ofrecen sobre las profesiones ejercidas por los diputados de nuestra muestra, nosotros hemos optado por determinar aquellas profesiones predominantes o más comunes a las que, con posterioridad, se les pudieran adscribir otras ocupaciones. Hemos privilegiado, en este sentido, al grupo de los abogados, tratando de ser coherentes con las afirmaciones que antes hemos formulado; pero también podríamos haber diluido el

10 En este sentido, para el caso francés, Bastid señala que los partidos políticos nacidos de la revolución favorecieron particularmente la entrada de juristas en sus filas con el fin de dotar al nuevo sistema liberal de la codificación y rigor legislativo que exigía su legitimación. BASTID, P.: Un juriste pamphlétaire, Cormenin, París, 1948, p. 171. Cit. en GARRIGOU, A.: «Le brouillon du suffrage universel. Archéologie du décret du 5 mars 1848», en Genèses (Paris) 6 (1991), pp. 161-178. 
protagonismo de este grupo dispersándolo en función de otras categorías que aludieran al ejercicio administrativo, la carrera universitaria o la tenencia de propiedades ${ }^{11}$. En cualquier caso, el criterio adoptado no enmascara algunas singularidades reseñables y todos los perfiles registrados aparecen incluidos en el siguiente cuadro:

\begin{tabular}{|l|c|}
\hline \multicolumn{2}{|c|}{$\begin{array}{c}\text { DISTRIBUCIÓN PROFESIONAL } \\
\text { (muestra de 66 diputados) }\end{array}$} \\
\hline ABOGADOS & 40 \\
\hline Abogado con bufete & 10 \\
\hline Abogado y magistrado & 6 \\
\hline Abogado y catedrático & 5 \\
\hline Abogado y propietario & 5 \\
\hline Abogado y periodista & 3 \\
\hline Abogado y funcionario & 2 \\
\hline Abogado, catedrático y funcionario & 3 \\
\hline Abogado, funcionario y propietario & 2 \\
\hline Abogado, magistrado y periodista & 2 \\
\hline Abogado, catedrático y propietario & 1 \\
\hline Abogado, catedrático y magistrado & 1 \\
\hline PROPIETARIOS & 11 \\
\hline Propietario & 10 \\
\hline Propietario, banquero y comerciante & 1 \\
\hline CATEDRÁTICOS & 3 \\
\hline Catedrático & 2 \\
\hline Catedrático y funcionario & 1 \\
\hline FUNCIONARIOS & 3 \\
\hline MILITARES & 3 \\
\hline PERIODISTAS & 1 \\
\hline BANQUEROS & 1 \\
\hline FARMACÉUTICOS & 1 \\
\hline MÉDICOS & 1 \\
\hline PROFESIÓN DESCONOCIDA & 2 \\
\hline
\end{tabular}

En relación con el predominio de los juristas en la Cámara puede observarse que no todos ellos vivieron de su titulación y que, los que lo hicieron, habi-

11 En este sentido, también nos ha parecido conveniente distinguir la ocupación de cátedras o magistraturas de otros empleos administrativos menos específicos. 
tualmente compartieron las funciones vinculadas a la abogacía con otras dedicaciones que, en un amplísimo repertorio, los relacionaron económica y profesionalmente con la ocupación de cátedras, la práctica literaria y periodística o el desempeño funcionarial. En este orden de cosas, de los 40 diputados identificables como abogados (60,6\% del grupo), sólo diez se dedicaron en exclusiva a su bufete, mientras que el resto compartió diversas profesiones bien de modo simultáneo o a lo largo de su vida. Lo más frecuente, sin duda, fue que el abogado se desenvolviese profesionalmente como magistrado: así ocurre, de hecho, en seis casos. Casi al mismo nivel aparecen también los abogados vinculados a la enseñanza — fundamentalmente a la universitaria - y con menor peso los empleados o funcionarios de la Administración pública. Con frecuencia, todas estas variables aparecen fusionadas en un solo individuo. Por ejemplo, Benavides es identificado en las fuentes bibliográficas y documentales de la época como abogado, magistrado y catedrático; Monares, por su parte, aúna las condiciones de abogado, catedrático y empleado. Por lo demás, curiosamente, una gran proporción de estos parlamentarios superpone a su ejercicio profesional habitual su trabajo como publicistas y, en general, la actividad periodística. Sucede esto último, al menos, en cinco casos, aunque no parece que a través del periodismo se persiguiese una compensación lucrativa, sino una contraprestación de prestigio o aprecio intelectual. Lo que sí, en cambio, puede ser un factor a tener en cuenta es que, a menudo, a la definición profesional del parlamentario se le incorpora la observación de que, además, es poseedor de

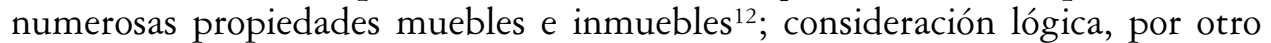
lado, si tenemos en cuenta que los altos niveles de renta exigidos a los candidatos electorales rara vez podían alcanzarse sólo recurriendo a los sueldos o ingresos por el trabajo efectivo. Este mismo argumento explicaría que, tras los abogados, el siguiente grupo con un peso específico propio dentro de la muestra sea el de los que se identifican única y exclusivamente como propietarios: 11 diputados (un 16,7\%), entre los cuales aparece el modelo de propietario agrario tradicional (Mencos) y también aquellos — como González Alegre o Ballesteros- que, en correspondencia con el despegue de nuevos sectores económicos, suman a la propiedad de la tierra las inversiones en la banca y en empresas de carácter mercantil. En cuanto al resto, tres catedráticos, un periodista, un banquero, un farmacéutico, un médico y tres militares continúan una nómina coronada por tres empleados que, por su reducido número, ponen en cuestión la reiterada afirmación y el extendido convencimiento de que el Parlamento español era una reunión de empleados públicos cautivos de los dictados políticos de la Administración del Estado.

12 Sobre la permanencia de los vínculos con la propiedad de la tierra, véase PRO RUIZ, J.: «La formación de la clase política liberal en España (1833-1868)», en Historia Contemporánea (Bilbao) 23 (2000), pp. 445-481. 


\section{3. «LAS ELECCIONES DEBEN SER LIBRES, PERO LA LIBERTAD NO ES LA ESPON- TANEIDAD»}

Atendiendo a su orientación ideológica y partiendo de la muestra inicial de 66 parlamentarios, hemos segregado un grupo de 18 diputados caracterizado por su predominante tendencia moderada ${ }^{13}$. Estos constituyen, desde el punto de vista de su perfil social, un conjunto bastante homogéneo y dotado de una serie de caracteres comunes o mayoritarios especialmente reseñables. Por ejemplo, seis de ellos disfrutaron de títulos de nobleza y acreditaron estar vinculados a familias hidalgas, proporción que cobra mayor significación relativa si tenemos en cuenta que el número de nobles en la muestra general se limita a 13 $(19,7 \%)$, secundando la opinión de Burdiel en relación a la «drástica reducción» en Valencia del espacio de actuación política de la nobleza ${ }^{14}$. Esta característica está, por lo demás, directamente relacionada con la común tenencia de propiedades raíces, muebles e inmuebles, circunstancia que se superpone frecuentemente a un ejercicio profesional derivado de la formación académica en el campo del Derecho. Ahora bien, al margen de las propias derivaciones que tiene la condición propietaria y sus implicaciones en el plano de la consideración social y el status, resulta igualmente expresivo, en una lectura política, que estos diputados obtengan sus actas electorales predominantemente en aquellos distritos en los que se concentra la propiedad agraria familiar. Ocurre así, al menos, de modo contrastado, en un $83 \%$ de los casos. A título demostrativo pueden servir algunas semblanzas particulares: la de Yáñez, por ejemplo, cuya familia acumulaba una importante propiedad terrateniente en torno al municipio de Monforte de Lemos y que siempre ocupó sus escaños en el Congreso como diputado por distintos distritos de la provincia de Lugo; o la de

13 Se trata de Gabriel Balbuena Ferreras, Antonio Benavides Fernández-Navarrete, Juan Francisco Camacho de Alcorta, Cristóbal Campoy Navarro, José María Claros Jarillo, Justo Pelayo de la Cuesta Núñez, José María Manresa Navarro, Cristóbal Martín de Herrera, Joaquín Ignacio Mencos Manso de Zúñiga, Fermín Gonzalo Morón, Cándido Nocedal y Rodríguez de La Flor, José de la Peña Aguayo, Pedro José Pidal Carniado, Cayo Quiñones de León Santalla, Ángel María Lucio del Rivero, Florencio Rodríguez Vaamonde, Luis José Sartorius Tapia, Ignacio Timoteo Yáñez de Rivadeneira. La mayor parte de ellos, además, se mantuvo dentro de la orientación política del moderantismo a lo largo de toda su vida, si bien algunos — cosa habitual en su época - exploraron también otras tendencias. Iniciado en la política dentro de las filas del Partido Moderado, Yáñez se incorporó con posterioridad a la Unión Liberal. Un recorrido similar cabe atribuir a Martín de Herrera. En cuanto a Cuesta, los repertorios biográficos de la época lo sitúan primero dentro del moderantismo, en el constitucionalismo en torno a 1877 y, finalmente, en 1880, dentro de las filas centralistas. Pero, sin duda, la más azarosa es la trayectoria ideológica de Nocedal, que pasó del progresismo al moderantismo en 1847 para acabar luego dentro de las filas neocatólicas y, por último, dentro del carlismo en 1869.

14 Se trata de Sartorius, conde de San Luis; Rivero, marqués de Montecastro; Balbuena, marqués viudo de Inicio; Pidal, marqués de Pidal; Mencos Manso, Barón de Biguezal y conde de Guendulain; y Quiñones de León, marqués de San Carlos. BuRDiEL, I.: «Análisis prosopográfico...», p. 127. 
Rivero, importante propietario de la provincia de Santander, que obtuvo, al menos, cinco actas vinculadas a esta demarcación. Peña, en Cabra; Martín de Herrera, diputado por Vitigudino entre 1859 y 1878; Mencos, propietario de varios mayorazgos en Navarra, provincia por la que salió elegido en numerosas ocasiones, o el mismo Pidal, en el entorno asturiano de Villaviciosa, del que era natural, constituyen ejemplos redundantes que aún podríamos prolongar componiendo una larga nómina que hace presumir, a todas luces, que el origen del predominio electoral y la naturaleza del poder político obtenido dentro del sector moderado tenían mucho que ver con la preeminencia económica y la existencia de fuertes cacicatos rurales sostenidos sobre una bien trabada red clientelar.

Ahora bien, a tenor de los datos de que disponemos, este modelo de político vinculado a la propiedad agraria que usufructúa las prebendas políticas de un cacicato familiar resulta en un gran número de casos perfectamente compatible con una intensa dedicación a la política y una estrecha relación con el mundo de la academia y la cultura. Así, dentro del grupo de los moderados que hemos deslindado, 12 se dedicaron asiduamente bien a la producción editorial en materias y disciplinas muy diversas, bien a la actividad periodística, como redactores o articulistas. En este orden de cosas, nombres tan conocidos como los de Nocedal, Pidal o Sartorius encabezan una relación en la que no resultan menos significativas las dimensiones periodística y literaria de Benavides o Mencos ${ }^{15}$. Integrados habitualmente en los foros académicos y culturales de la época que mayor prestigio garantizaban — como el Ateneo de Madrid o las Academias de Ciencias Morales y Políticas, y de Jurisprudencia y Legislación-, se prodigaron con frecuencia en sus tribunas pronunciando discursos de temas muy diversos, aunque casi siempre relacionados con la Jurisprudencia o la Historia. En realidad y con vistas al tema que nos concierne, tan sólo a Fermín Gonzalo cabe atribuir la publicación de obras directamente relacionadas con cuestiones legislativas y, al menos, tangencialmente inspiradas en el debate sobre los modelos de representación política imperantes en la Europa de mediados del siglo $\mathrm{XIX}^{16}$.

No hubo, por tanto, entre los diputados moderados que intervinieron en la confección de la legislación electoral española grandes expertos en el tema que orientaran parte de su producción bibliográfica a estas cuestiones, lo cual tampoco es necesariamente indicativo de que el problema no les preocupara o no fuera objeto de su interés como eruditos y lectores. De hecho, la activa presen-

15 Aparte de ser fundador de La Constancia y de El Siglo Futuro, Nocedal escribió frecuentemente en otros periódicos, como El Padre Cobos o La Gaceta de Madrid. Del mismo modo, Sartorius está vinculado a la fundación de El Heraldo y Pidal, redactor habitual de El Espectador, a la puesta en marcha de El Aristarco. Por su parte, otros como Benavides o Mencos colaboraron, respectivamente, como articulistas en El Correo Nacional y El Articulista. En un plano más especializado, Manresa ocupó la dirección de la Revista General de Legislación y Jurisprudencia y de la Revista Penitenciaria.

16 Vid. GONZALO MORÓN, F.: Ensayo sobre las sociedades antiguas y modernas y sobre los gobiernos representativos, Madrid, 1844. 
cia de ellos en los debates parlamentarios abiertos en torno a estos temas podría ser, precisamente, señal de todo lo contrario, especialmente si tenemos en cuenta que estas intervenciones se produjeron no sólo mientras el Partido Moderado ocupaba los bancos de la oposición, sino también durante sus prolongadas etapas de Gobierno. Así, en pleno período isabelino y mientras el Partido Moderado asumía las funciones del poder ejecutivo, muchos moderados contribuyeron a la elaboración de la legislación electoral defendiendo el proyecto que habría de convertirse en la Ley Electoral de $1846^{17}$, pero también aportando enmiendas y proposiciones de ley que perseguirían en lo sucesivo un mejoramiento de ésta.

Sin lugar a dudas, en este orden de cosas, uno de los temas que más preocuparon a los moderados y que más debate interno provocó fue el de las incompatibilidades parlamentarias. Aunque aparecía entonces encuadrado en la llamada «oposición conservadora», Fermín Gonzalo encabezó en noviembre de 1849, junto a otros moderados discrepantes como Nocedal, Benavides, Polo o Campoy ${ }^{18}$, una proposición de ley que pretendía reforzar el sistema de incompatibilidades limitando la presencia de los empleados públicos y dependientes del Estado en el Parlamento y favoreciendo, en cambio, una estrecha vinculación - por razón de naturaleza o de interés económico- del diputado y su distrito. Este mismo tema ya había sensibilizado a otros moderados, como Rivero, Yáñez o Rodríguez Vaamonde durante la discusión de la ley a comienzos de 1846, aunque de un modo menos restrictivo, exceptuando siempre a los funcionarios madrileños y no renunciando a aprovechar la experiencia de los empleados en la gestión y manejo de los asuntos públicos ${ }^{19}$. Desde una abierta oposición, el tema volvería a aflorar años más tarde. Martín de Herrera y el marqués de San Carlos, en 1862, y Nocedal, en 1866, insistirían en revisar la cuestión, aunque el último presentaría una proposición de ley mucho más radical, que sólo consentía a los ministros el doble ejercicio de la función pública y la representación parlamentaria. Aunque en su defensa estuvo apoyado por el elocuente moderado Claros, otro correligionario, Cuesta, se opondría a él argumentando que era imposible y antiliberal establecer una separación total entre la Administración y el poder legislativo ${ }^{20}$.

Tras la controvertida cuestión de las incompatibilidades, fue el tema de los requisitos contributivos de los elegibles el que mayor preocupación suscitó en-

17 «...dejamos a los ministros de la Corona la satisfacción de gobernar el país como lo están haciendo», afirmó complacientemente Peña durante la discusión del citado proyecto. DSC, 5-21846, p. 542. Una defensa similar cabe atribuir a Benavides, miembro de la Comisión que se encargó de dictaminar sobre el proyecto. Vid., por ejemplo, sus intervenciones en DSC, 5 a 7-2-1846.

18 De hecho, Burdiel aclara que, desde 1848, Gonzalo Morón había liderado una corriente de oposición a Narváez en la que se integraban también algunos «progresistas templados». BURDIEL, I.: «Análisis prosopográfico...», p. 137.

19 DSC, 3-12-1849 y 5-2-1846.

20 DSC, $10-3-1862$ y $20-3-1866$. 
tre algunos miembros de las filas moderadas. En el sentido de elevar sustancialmente los niveles de rentas exigidos en el Proyecto de la Ley de 1846 se pronunció el diputado Rivero al encabezar ese mismo año, junto a varios progresistas, una enmienda que pretendía garantizar la independencia económica y política del diputado. Desde otra perspectiva, Mencos y Balbuena abogaron por un cambio en el sistema de elaboración de las listas de electores, suscribiendo una enmienda en la que se pedía la sustitución del sistema de renta mínima por el de inclusión de los 200 mayores contribuyentes del distrito ${ }^{21}$. Lo normal en este punto, no obstante, es que el moderantismo abogase por mantener un control estricto sobre la incorporación de nuevos electores al censo; aspecto éste que Camacho defendió encarnizadamente en 1856 acusando al Partido Progresista de estar estableciendo el sufragio universal «de manera vergonzante», pues éste pretendía rebajar la cuota mínima de 200 reales de renta ${ }^{22}$.

Finalmente, la persecución de los delitos electorales también centró de manera dispar el interés de algunos moderados. Así, por un lado, Claros, que participó en 1864 en la Comisión encargada de dictaminar acerca del Proyecto de Ley de Cánovas sobre sanción de delitos electorales, se adscribió a la defensa del citado proyecto, en tanto que Cuesta y Campoy firmaron una enmienda contra él por entender que este tipo de delitos no podría erradicarse mientras la potestad de elaborar el censo electoral continuase en manos del ejecutivo. En su opinión, toda la ley podía ser sustituida por un par de artículos que fijasen el castigo del delito electoral con arreglo al Código Penal y que hiciesen recaer su juicio en los tribunales de la jurisdicción común ordinaria. Ambos moderados, situados en una discreta oposición discrepaban en cuanto a dar o no legitimidad a las influencias ejercidas por el Gobierno con respecto a los electores, pero coincidían al situar la clave del problema en la confección de las listas electorales ${ }^{23}$.

Como puede observarse, en el trasfondo ideológico de estos debates lo que subyacía era una fuerte preocupación por delimitar el ámbito y naturaleza de la representación política y una sustancial falta de acuerdo interno en torno a qué influencias políticas podían o no considerarse legítimas. La resolución de estas diatribas llevó a las filas moderadas en no pocas ocasiones a sostener posiciones contradictorias que propiciaron frecuentes discrepancias observables en la divergencia del voto o en la suscripción de proposiciones y enmiendas junto a miembros de otros partidos. En cualquier caso, vinieran o no de sus propias filas, los gobiernos moderados consideraron siempre que cualquier rectificación o mejoramiento de la legislación electoral debía responder a la iniciativa e intervención del ejecutivo y rechazaron sistemáticamente cualquier injerencia externa, incluso cuando venía a coincidir con su filosofía política oficial.

21 DSC, 4 a 6-2-1846.

22 DSC, 31-1-1856, p. 10.436.

23 DSC, 22 y 30-3-1864, y 2-4-1864. De hecho, en 1865, Claros firmó una enmienda al Proyecto de Ley de Posada Herrera pidiendo que las listas electorales fueran realizadas por el poder judicial y no por el poder ejecutivo. DSC, 3-7-1865. 
Pero irealmente ésta existía? Cánovas afirma que «los ideólogos del Partido Moderado sólo fueron capaces de elaborar una doctrina política imprecisa, fragmentaria y de escaso rigor, en torno a una serie de ideas básicas como el fortalecimiento del poder real, la defensa de la propiedad, la síntesis de los dos pasados incompletos, el orden público...» ${ }^{24}$. Con él coincide Romeo al subrayar que, si algo faltó precisamente dentro del moderantismo español, esto fue el consenso interno y un concepto unívoco de la política y el Estado que fuese más allá de algunos lugares comunes: la superación de las turbulencias revolucionarias, el imperio del orden y la consagración de la autoridad ${ }^{25}$. Esta falta de un programa político creativo y renovable explicaría, de hecho, la relativa facilidad con que algunos moderados, como se ha visto, excluidos del núcleo central del partido por su heterodoxia y espíritu conciliador, se incorporaron a otros espacios ideológicos limítrofes como el neocatolicismo o el progresismo, colaborando con ellos durante el desarrollo de las tareas legislativas y, sobre todo, dando carta de naturaleza a la argumentación de Camacho al afirmar en 1856 que, en lo relativo a la legislación electoral, «no hay divergencia esencial entre las opiniones del Partido Progresista y las del Partido Moderado» ${ }^{26}$.

Pero lo cierto es que el espacio ideológico que quedaba entre el rechazo del absolutismo y la defensa de la democracia, entre el miedo a la involución y la contención revolucionaria, era lo suficientemente extenso como para que, dentro de él, pudieran entremezclarse concepciones muy diversas de la política y de la sociedad —unas más reaccionarias y otras más innovadoras - nacidas de posicionamientos sociales, económicos y culturales que la prosopografía revela igualmente diversos y nutridas al paso de una irregular trayectoria histórica que se reforzaría, precisamente, con la lucha por el poder entre moderados y progresistas ${ }^{27}$.

Aunque ningún moderado negaba su preocupación por la distancia cada vez mayor que estaba separando a Gobierno, Parlamento y «nación», y todos se atribuían la condición de adalides de la pureza y verdad del sistema representativo, el moderantismo se adscribía en conjunto a la teoría del liberalismo

24 CÁnovas, F.: El Partido Moderado, Madrid, 1982, p. 297.

25 ROMEO MATEO, M.C.: «Tras los escombros de la revolución. El moderantismo y las estrategias políticas y culturales de dominación», en FUENTES, J.F., y ROURA, LL. (eds.): Sociabilidad y liberalismo en la España del siglo XIX, Lleida, 2001, pp. 242 y s. Esta tesis aparece también tratada por la misma autora en «Lenguaje y política del nuevo liberalismo: moderados y progresistas, 1834-1845», en Ayer (Madrid) 29 (1998), pp. 37-62. Acerca del doctrinarismo español sigue siendo una lectura inexcusable la de DíEz Del CORRAL, L.: El liberalismo doctrinario, Madrid, 1984, esp. pp. 521 y ss.

26 DSC, 31-1-1856, p. 10.435.

27 En este sentido, Gómez Ochoa ha afirmado que las diferencias de grado o talante entre moderados y progresistas se ahondaron como consecuencia de su rivalidad por la ocupación del poder llegando a definir «dos formas distintas de entender y obrar el liberalismo». Gómez OCHOA, F.: «Pero chubo alguna vez once mil vírgenes? El Partido Moderado y la conciliación liberal, 18331868», en SuÁrez CORTiNA, M. (ed.): Las máscaras de la libertad. El liberalismo español, 1808-1950, Madrid, 2003, pp. 135-168, p. 139. 
doctrinario que distinguía entre derechos naturales y derechos políticos del individuo, marcando entre ellos una frontera intraspasable, y hacía depender de este argumento la mayor parte de su discurso político. En este sentido, el convencimiento de que correspondía al poder ejecutivo el ejercicio de un imprescindible control social y político del régimen representativo constituyó un inexcusable punto de convergencia interna dentro del partido. En su intervención parlamentaria de 1864, Claros, concedería absoluta legitimidad a la «influencia moral del Gobierno" con una paradoja en la que afirmaba que "las elecciones deben ser libres, pero la libertad no es la espontaneidad». Según él, el Gobierno debía encarnar la razón y el buen sentido, de modo que estaba naturalmente legitimado para orientar la voluntad política de los electores sin menoscabo alguno de la libertad de éstos. Equiparando las funciones del ejecutivo a la misión protectora de un padre, consideraba que la intervención del Gobierno en materia electoral constituía en esencia un deber del mismo. Curiosamente, Claros limitaba de modo drástico el ejercicio de este deber cuando se trataba de aplicarlo a la más distinguida y capacitada categoría de los elegibles, pero lo aplaudía entusiastamente cuando se ejercía sobre un electorado que, a un mismo tiempo, temía y minusvaloraba.

Un enraizado temor a la "plebe» constituía, de hecho, uno de los puntos claros de convergencia del heterogéneo ideario moderado. No lo era menos, desde luego, la minusvaloración del elector. Y, en este punto concreto, el moderantismo subrayó exageradamente la frontera que lo separaba del progresismo, esa ideología que, en palabras enfáticas de Donoso Cortés, pretendía extender «el derecho electoral hasta los últimos límites posibles» y que sistemática y premeditadamente era confundida por los moderados con la perturbadora opción demócrata ${ }^{28}$. Los diputados moderados de nuestra muestra dan buena cuenta de ello. Según Benavides, 80 o 90.000 electores, dadas sus condiciones, sobraban para sostener el sistema representativo. Para Rodríguez Vaamonde, que no dudó en definir el sufragio universal como una «desacreditada utopía», «el elector ni conoce el uso y la importancia de su derecho, ni tiene voluntad propia, ni es más que el instrumento del poderoso o del intrigante», lo cual justificaba que su decisión política se orientase desde arriba. Incluso un moderado más aperturista, como Gonzalo Morón, justificaba la injerencia electoral del Gobierno, siempre que quedase preservada la independencia del elegible. No preocupaba al moderantismo, en consecuencia, la libertad de voto de los electores, sino la libertad de actuación de los elegidos, una categoría reservada a las clases propietarias e ilustradas. En este caso, en lugar de la influencia gubernativa, Claros legitimaba factores influyentes como el

28 Donoso Cortés, J.: Artículos políticos en «El Piloto», Pamplona, 1992, p. 179. A respecto del posicionamiento del progresismo español ante el sufragio, puede verse BURDIEL, I.: «La tradición política progresista. Historia de un desencuentro», en DARDÉ, C. (ed.): Sagasta y el liberalismo español, Madrid, 2000, p. 118. 
parentesco o la amistad y Gonzalo aseveraba que las influencias locales, lejos de perjudicar al sistema representativo, proporcionaban a éste una base sólida sobre la que sustentarse, mientras que el apoyo del Gobierno al candidato constituía un envilecimiento de la representación política ${ }^{29}$.

No obstante, para otros, las fronteras entre las influencias ejercidas desde el Gobierno y las que emanaban de los propios distritos distaban mucho de estar definidas, pues ambos mecanismos venían a desarrollar de manera complementaria el tan ansiado control social al que se aspiraba. En este sentido, el propio Nocedal, como Ministro de la Gobernación, aseguraría en 1857 que el Gobierno, legítimamente, no imponía candidatos, sino que respaldaba los que se les recomendaban como «candidatos naturales» desde los distritos. Con afirmaciones como ésta, el caciquismo, en sus dos principales dimensiones _ gubernamental y local_-, aparecía, en última instancia, como el verdadero cauce de la representación política y el Gobierno, a fin de cuentas, como garante de los derechos de la sociedad frente al individuo y como baluarte contra el caos. La inhibición gubernativa ante las urnas hubiera supuesto — afirmaba Nocedal— «entregar la sociedad a la anarquía» ${ }^{30}$.

Sin duda, la preocupación por la independencia de la clase política con respecto al Gobierno desvió la atención del moderantismo hacia el tema de la presencia de los funcionarios en los escaños del Congreso, dejando en un segundo plano las cuestiones que concernían al elector y al reconocimiento de sus derechos civiles. En 1866, uno de los discursos de Claros hizo brotar las risas del hemiciclo al lanzar un sarcástico vituperio contra el diputado-empleado, que no reunía, a su juicio, las características de «disipación, intriga y lujo» exigibles a todo parlamentario y que, sobre todo, carecía de la independencia imprescindible $^{31}$. Sin embargo, no todos los moderados fueron tan extremados en sus consideraciones ni pidieron, como Claros, una exclusión tan radical del empleado. En mayor o menor grado, como hemos visto, fueron comunes las reclamaciones de una regulación específica de las incompatibilidades y casi todos centraron el problema en la dependencia del funcionario con respecto al poder ejecutivo. Tan sólo a Martín de Herrera, excepcionalmente, cabe atribuir una visión algo más compleja del problema, pues fue él el único que añadió a este tipo de dependencia, la que se generaba entre el diputado-empleado y los intereses de su localidad. Así, el funcionario solía obtener sus votos a cambio de favores administrativos repartidos entre los electores y acababa sometido a los dictados de éstos, convirtiéndose en un agente de los intereses de su distrito y no en un representante de la nación ${ }^{32}$. Desde luego, ni que decir tiene que esta

29 DSC, 21-3-1864, p. 1.233; 6-2-1846, p. 578; 4-2-1846, p. 533. En su propio descargo, Fermín Gonzalo llegaría a afirmar: «...yo tengo por envilecimiento el que un diputado necesite para serlo de la influencia del Gobierno». DSC, 3-12-1849, p. 280.

30 DSC, 25-5-1857, p. 169.

31 DSC, 20-3-1866, pp. 687 y s.

32 DSC, 10-3-1862, pp. 1.352-1.354 
inquietud por las raíces clientelares y caciquiles de la representación política no se dejó ver en el Parlamento como una preocupación candente de los moderados que componen nuestra muestra.

En cuanto a los modelos europeos a seguir, tampoco existió un acuerdo pleno. Para un cierto sector del moderantismo, que, en nuestro caso, representan Gonzalo y Martín de Herrera, Inglaterra constituía un referente ineludible en el que el sistema representativo y la legislación electoral debían inspirarse, aunque sin dejar de observar con interés la realidad francesa, precisamente, para no repetir los mismos errores que el país vecino. En cambio, el grupo predominante dentro del Partido Moderado, del que podemos considerar exponente al diputado Rodríguez Vaamonde, asimiló la herencia ideológica de los años de exilio y vio en la experiencia legislativa francesa una guía ineludible y, en el orleanismo, un modelo gubernativo flexible que permitía, a un tiempo, la imitación y la adaptación a las particularidades de la vida política española ${ }^{33}$. De hecho, Cánovas subraya el decisivo influjo que la Francia orleanista tuvo en el moderantismo español, adscribiéndolo a un estilo político caracterizado por el eclecticismo y la historicidad, es decir, por la voluntad de sintetizar un «justo medio» y el interés por adaptarse a las circunstancias concretas de cada tiempo y lugar ${ }^{34}$.

\section{4. «EL VERDADERO PARTIDO MEDIO»}

Del conjunto de diputados seleccionados, 27 son progresistas, siendo éste por lo tanto el grupo partidista más nutrido dentro de nuestra muestra ${ }^{35}$. Este primer dato resulta ya de por sí indicativo del interés que la representación política despertó dentro del progresismo, que, a pesar de su breve paso por el gobierno, activó continuamente con su presencia parlamentaria el debate sobre la legislación electoral y sus problemas.

Por lo que se refiere al perfil prosopográfico del grupo, sus características socioeconómicas responden al patrón general ya analizado, pero presenta algu-

33 GÓmeZ OCHOA, F.: Op. cit., p. 142.

34 CÁnovas, F.: Op. cit., pp. 298 y s.

35 Son Joaquín Aguirre de la Peña, Mariano Ballesteros Dolz, Pedro Bayarri Benedito, Juan Andrés Bueno Prado, Pedro Calvo Asensio, Fernando Corradi Gómez, Manuel de la Cortina Arenzana, Jacinto Félix Domenech Sastae, Patricio de la Escosura Morrogh, Laureano Figuerola y Ballester, Diego María García Martínez, Valentín Gil Virseda, Rodrigo González Alegre, Venancio González Fernández, Antonio González González, Modesto Lafuente Zamalloa, Pedro López Grado, Pascual Madoz Ibáñez, Antonio Méndez Vigo, Rafael Monares Cebrián, José Moreno Nieto, Alonso Navarro Rodríguez, Salustiano Olózaga Armendoz, Antonio Rivero Cidraque, Tomás Rodríguez Pinilla, Práxedes Mateo Sagasta Escolar y Evaristo San Miguel Valledor. Aunque algunos de ellos militaron también en otras formaciones políticas — básicamente en la Unión Liberal—, su intervención más significada en el debate electoral se hizo desde el partido progresista. 
nos matices que, además de ayudar a explicar el modelo de representación defendido, pueden informarnos sobre la base social de este partido. De forma más significativa que la formación académica (mayoritariamente jurídica, como en el conjunto de la muestra), la dedicación profesional de los diputados progresistas indica un alto grado de presencia en ámbitos laborales relacionados con la administración pública y con un ambiguo sector de servicios en el que fue habitual la práctica simultánea de varias ocupaciones. El 62,9\% se define como abogado, pero esta denominación engloba realidades tan diversas como la ocupación de cátedras universitarias (23\%), el desempeño de cargos públicos $(17,6 \%)$, la carrera judicial $(11,7 \%)$ y, en proporción muy inferior, la efectiva abogacía en libre ejercicio $(5,8 \%)$. Además, la condición de propietarios complementa con aún más frecuencia la caracterización de abogados (41\%), por lo que parece evidente que el sustento material fundamental de buena parte de estos parlamentarios debió de estar antes en las rentas de sus propiedades que en el ejercicio profesional, en lógica relación con los requisitos censitarios vigentes durante la mayor parte del periodo analizado. Por otra parte, entre los diputados que se definen exclusivamente como propietarios, la aparición de algunos participantes en empresas mercantiles o financieras (los casos de Ballesteros y González Alegre), junto a la más generalizada propiedad agraria, no sería sino un indicador de la combinación de formas de riqueza nuevas y tradicionales característica de la estructura económica general del país en una época de cambios.

Pero aunque el disfrute de una renta fuera aún una realidad generalizada entre la elite política española, los diputados progresistas de esta muestra proporcionan también ejemplos de cómo la esfera publica se iba abriendo a individuos que no contaban necesariamente con esta plataforma previa. Así, la prensa - con nombres cruciales para el progresismo en su calidad de portavoces del partido, como Calvo Asensio y La Iberia, Corradi y El Clamor Público, o López Grado y El Progreso Constitucional_- la Universidad — con intelectuales como los catedráticos Aguirre, especialista en Derecho eclesiástico y publicista de la libertad religiosa, Figuerola, el más reputado economista español del siglo XIX, o Rodríguez Pinilla, introductor del krausismo en la Universidad de Salamancay el ejército —origen profesional de líderes progresistas tan significados como Escosura y San Miguel_-, fueron otras plataformas alternativas que algunos progresistas recorrieron en su camino entre la profesión y la política. Desde luego, tampoco son extraños los casos de trayectorias vitales (Bueno, López Grado, Rivero Cidraque, Sagasta...) en las que el ejercicio libre o funcionarizado de una profesión liberal se vería complementado con el acceso a distintos tipos de propiedad. Se trata de un proceso de reforzamiento de los fundamentos del ascenso social que fue frecuente en el contexto de la construcción del Estado y la economía liberales, y que interesaría especialmente al tipo de «gentes nuevas» que, según Pan-Montojo, define sociológicamente al progresismo isabelino ${ }^{36}$.

36 Pan-Montojo, J.: «El progresismo isabelino», en SuARez Cortina, M. (Ed.): La redención del pueblo. La cultura progresista en la España liberal, Santander, 2006, pp. 183-208. 
En otro sentido, la información que proporcionan los datos sobre sus carreras políticas y públicas evidencia que, de forma mayoritaria, nos encontramos ante un grupo de diputados caracterizado por una presencia continuada y activa en esta esfera. La relativa juventud media de la muestra no debe ocultar un fenómeno generalizado de trayectorias parlamentaria extensas, como demuestra el elevado número de actas electorales logradas, e intensas: fueron, por lo general, diputados activos que participaron como miembros de comisiones dedicadas a materias constitucionales, imprenta, jurados, relaciones IglesiaEstado, y como promotores de proposiciones de ley, enmiendas o interpelaciones sobre éstas y otras cuestiones- El conocimiento de la política cotidiana y de los mecanismos de funcionamiento del Estado, además de verse avalado por este tipo de cursus honorum, estaría en algunos casos reforzado por el desarrollo de carreras administrativas. Sin que ninguno de los diputados progresistas de esta muestra puedan ser considerados simplemente como empleados públicos, pues complementaron esta dedicación con otros trabajos o ingresos, cuatro de ellos entraron en la política desde el funcionariado. Se trata de un porcentaje seguramente inferior al que afectaría al conjunto del grupo parlamentario progresista, pues, como se puso en evidencia durante el debate sobre incompatibilidades, este partido contaba entre sus filas con un alto número de empleados públicos, un apoyo social que se compadecía más mal que bien con el discurso oficial progresista, en su origen radicalmente contrario a la presencia de funcionarios en las Cámaras ${ }^{37}$. Así pues, no sólo la administración era cantera de parlamentarios, sino que los diputados, en el ejercicio de su labor legislativa, se enfrentaron a algunos problemas desde su visión de funcionarios, como sucedió en este polémico tema de las incompatibilidades. Aunque en principio la teoría progresista censuró duramente al diputado-empleado, figura que había comenzado a ser un socorrido recurso de control gubernamental durante la década moderada, en los años cincuenta y a instancias preferentemente de diputados que eran precisamente funcionarios — como Sagasta—, experimentó un proceso de redefinición ideológica que, suavizando las incompatibilidades parlamentarias, terminó por acercar las posiciones progresistas a las moderadas, mientras que desde los extremos del neocatolicismo y el republicanismo se continuó coincidiendo en la defensa de la incompatibilidad absoluta ${ }^{38}$.

37 Durante el debate de una enmienda a favor de incompatibilidades estrictas, el diputado progresista Ruiz Gómez avisó que su aplicación supondría «privar a nuestro partido de los hombres más eminentes y que más servicio han prestado en las luchas políticas desde el principio de siglo acá». Escosura coincidió, oponiéndose a «un divorcio completo entre todos los funcionarios públicos y la causa del progreso»: «¿En qué posición queréis colocarnos? ¿En la que ni podamos valernos de nuestros amigos, de los que han padecido once años como nosotros?». DSC, 14-2-1856, p.10.732 y 10.744 , respectivamente.

38 Sagasta presentó una enmienda para reducir notablemente las incompatibilidades en las Bases de la Ley Electoral de 1856, defendiéndola sobre su ejemplo personal y con argumentos en los que combinaba la apelación práctica de no desperdiciar bases sociales del partido con una disertación sobre la «verdadera» independencia política, DSC, 15-2-1856, pp. 10.766-10.785. 
Pero junto al diputado de dedicación estable vinculado a la función pública, el partido progresista contó también con otros cuya base material estuvo por el contrario en las propiedades adquiridas en sus comarcas de origen. Este tipo de diputado acuñó en los debates parlamentarios un discurso sobre la legitimidad del representante que, muy crítico con la posible independencia política del diputado-empleado, afirmó con rotundidad la necesidad de sustanciar la representación de la nación en personas que, por ser los propios dueños de sus medios de subsistencia, garantizarían la única independencia política cierta. Así González Alegre, diputado por Toledo, donde era propietario, banquero y comerciante, señaló la diferencia entre quienes «viven en Madrid» y «tienen forzosamente que guardar (...) ciertas consideraciones», y quienes desde provincias «hemos venido sin aspiraciones personales de ningún género», sólo para «ser intérpretes de la opinión de nuestros comitentes»39.

Independientemente del origen económico y de la dedicación profesional, el grupo de los diputados progresistas que se ocupó de la legislación electoral durante todo el periodo estudiado se caracterizó por una presencia frecuente en los círculos intelectuales oficiales de aquella época, compartiendo asiento con moderados y unionistas en las Academias de Jurisprudencia, de Ciencias Morales y Políticas, y de la Lengua, en el Ateneo de Madrid, o en Sociedades Económicas, Arqueológicas y de otro tipo. Y, al igual que otros liberales conservadores, muchos de ellos desarrollaron una prolífica y poco conocida actividad publicística. Varios de estos diputados progresistas dedicaron ensayos de diversa naturaleza a una extensa nómina de materias jurídicas y filosóficas de su respectivas áreas de especialización -Derecho canónico o procesal, novedades del pensamiento político social europeo de la época, Derecho constitucional comparado-, pero también se ocuparon sobre aspectos concretos de la ordenación de derechos y libertades que se estaba configurando con el régimen liberal español — como la libertad religiosa o la cuestión de los jurados- ${ }^{40}$. Aunque sin atender específicamente a la idea de la representación política, y más

39 DSC, 7-4-1870, pp. 7.175-7.177. Como hemos expuesto en otro trabajo, la difícil articulación de ambas procedencias sociales dificultó la construcción cultural de la figura del diputado, cuestionando su legitimidad, durante toda la época isabelina. PeÑA, M.A.; Sierra, M. y Zurita, R.: Op. Cit.

40 Aguirre de la Peña fue el autor de un curso de derecho canónico de gran éxito en medios universitarios, Curso de disciplina eclesiástica general y particular de España, cuya primera edición se hizo en Madrid en 1848; fue también autor de Reformas necesarias para que la justicia se administre pronta y cumplidamente (1861) y Reformas procesales (1862). En defensa de la libertad religiosa fue famosa su confrontación con el Obispo de Barcelona, publicada en forma de Carta del Excmo. Sr. D. Joaquín Aguirre, Diputado a Cortes y Ex-Ministro de Gracia y Justicia al Excmo. e Ilmo. Sr. D. José Domingo Costa y Borrás, Obispo de Barcelona (1856). Entre la extensa obra de Figuerola figuran Organización política del Estado. Discurso en la Academia Matritense de Legislación (1854) y Filosofía del Trabajo: Memoria leída ante la Real Academia de Ciencias Morales yPolíticas (1884). Escosura se ocupó del Derecho constitucional en obras como Diccionario Universal de Derecho Español Constituido (1852-1853) e Historia Constitucional de Inglaterra (1859-1860). Lafuente escribió sobre La cuestión religiosa (1855) y Rodríguez Pinilla sobre El establecimiento del jurado (1882). 
allá de su muy diferente calidad intelectual y literaria, esta actividad puede resultar significativa del tipo de compromiso en la esfera política de estos diputados, ya que implica un esfuerzo extra de construcción intelectual, añadido a su protagonismo en la gestión de la actividad parlamentaria.

Al reconstruir desde el debate parlamentario el concepto de representación política defendido por los progresistas a lo largo del siglo XIX, la primera barrera interpretativa que hay que superar es la coincidencia de sus muy diversos adversarios al criticar su incoherencia ideológica y práctica. Las acusaciones de volubilidad en el dilema entre la concepción del sufragio como derecho natural —inherente a todos los hombres - o el sufragio como capacidad — restringido a quienes podían ejercerlo con garantías de independencia-, que surgieron de la confrontación partidista, encontraron fácil argumento en las cambiantes opciones del partido progresista, que, de hecho, oscilaron varias veces entre la democracia y la restricción censitaria del voto, desde sus teóricos orígenes doceañistas hasta su desaparición como tal partido durante el sexenio revolucionario. El esfuerzo del progresismo por definirse como un partido de orden y de gobierno en la década de 1830 implicó, como ha indicado Romeo, un proceso de reordenación ideológica que conllevaba, entre otras cuestiones, la aceptación de las doctrinas posrevolucionarias europeas que relacionaban la representación con la «razón»y no con el «número», abandonando el sistema electoral gaditano, caracterizado éste por la extensión universal del sufragio, aunque también por otros elementos — voto indirecto, primacía de las autoridades locales, concepción historicista de la nación - muy alejados de una visión individualizada de los derechos políticos que tardaría tiempo en aparecer en el liberalismo español ${ }^{41}$.

La debilidad política que podía derivarse del cambiante posicionamiento oficial del progresismo sobre el derecho al voto se agravó, además, por la existencia de distintas corrientes internas dentro del partido, que acabarían provocando desgajamientos por la izquierda (no sólo la formación del partido demócrata en 1849, sino ulteriores trasvases al ámbito del demorepublicanismo) y por la derecha (la incorporación de importantes activos del progresismo a la Unión Liberal a partir de 1856), a la vez que dificultaron la cristalización de un partido de «centro liberal» como el deseado por algunos de los progresistas más característicos $^{42}$. No cabe duda de que bajo el nombre de partido progresista se englobaron discursos muy distintos, cercanos en algunos casos al liberalismo

41 La definición del progresismo como partido de orden en RomeO MATEO, M ${ }^{\mathrm{a}}$.C.: «Lenguaje y política...». Sobre el modelo de representación política del liberalismo gaditano, PORTILLO VALDÉS, J.M ${ }^{\mathrm{a}}$.: Revolución de nación: orígenes de la cultura constitucional en España, 1780-1812, Madrid, 2000.

42 Para las distintas facciones en el progresismo, OlLero VALLES, J.L.: «Las culturas políticas del progresismo español: Sagasta y los puros», en SuÁREZ CoRTinA, M. (Ed.): La redención del pueblo..., pp. 239-269. La referencia al progresismo como un partido de centro en Escosura: «El progresista, señores, si hubiera lógica en las denominaciones, sería el único que se podía llamar moderado, el único: el que está entre la teoría democrática y la oligárquica; ese es el verdadero partido medio», DSC. 31-1-1856, p.10.439. 
más conservador de moderados y unionistas, y, en el otro extremo, a posiciones similares a las de demócratas y republicanos. Pero, en el segmento central de este espacio se acuñó un modelo de representación política que, aunque no pudo llevarse nunca a la práctica, fue definido con detalle en las Bases del Proyecto de Ley Electoral de 1856, y que, mucho más allá de la forzada aceptación del sufragio universal hecha luego en la década de 1860, representa, en su filosofía de ampliación ordenada del sufragio, la esencia reformista del progresismo.

En la definición de la figura del elector, el proyecto progresista se diferenció del moderado en una concepción flexible del requisito censal exigible, que se presentó como una cuota en progresiva reducción. En palabras del diputado López Grado, en nombre de la comisión encargada de redactar las Bases del Proyecto, se debía ir «tendiendo siempre (...) a reducir la cuota según los progresos y adelantos de la sociedad», porque «deseamos ir poco a poco caminando al punto de parada: el sufragio para todos cuando el tiempo, las luces y las circunstancias política lo reclamen» ${ }^{43}$. Sin duda la apelación al sufragio universal tiene mucho de recurso discursivo, y posiblemente los progresistas españoles abanderaron su defensa porque, al igual que los liberales franceses que lo reclamaban antes de la revolución de 1848, estaban convencidos de que no iba a ser efectivamente implantado ${ }^{44}$. No obstante, este tipo de recurso discursivo no solamente allegaría apoyos sociales populares a un partido que, como señala Burdiel, contó en este sentido con un respaldo que el moderantismo se esforzó en anular con el contrapeso de una Corona secuestrada ${ }^{45}$, sino que también influiría sobre una concepción del progreso histórico que permitió a los llamados progresistas «puros» (Madoz, Escosura, Calvo Asensio...) mantener una visión optimista sobre la movilización política de la sociedad.

Para la mayoría de los progresistas, el modelo a imitar era el británico. Junto a la marcada anglofilia de un Olózaga, es frecuente topar con referencias al sistema electoral británico como principio de autoridad en los discursos parlamentarios de otros diputados progresistas menos conocidos como Méndez y Antonio González. Más frecuente aún fueron las alusiones negativas al modelo francés a partir del giro conservador que siguió a la revolución de 1848. Lo sucedido en la Francia de Napoleón III confirmó a los progresistas españoles que la ampliación del derecho al voto no podía hacerse de forma total e inmediata sino que tenía que resultar de un proceso graduado y dirigido: ese era el

43 DSC, 22-1-1856, p.10.030.

44 Según Chevallier, en la Francia de 1848 ningún grupo deseaba en realidad la implantación del sufragio universal. Cit. en GARrigou, A.: Op. Cit. p.163. Entre los liberales españoles, el uso retórico de la democracia se pone especialmente en evidencia en el ala derecha del progresismo: diputados que acabaron ingresando en la Unión Liberal como resultado de su temor al desbordamiento de la participación social, como Moreno Nieto, a la vez que mantenían un discurso catastrofista sobre la movilización de las masas, reconocían también como fin deseable la democracia, siempre que fuera una democracia «armónica y cristiana», DSC, 24-1-1856, pp. 10.168-10.170.

45 BURDIEL, I.: Isabel II. No se puede reinar inocentemente, Madrid, 2004. 
espacio para el «espíritu prudente» de un progresismo que afirmaba definirse por su separación de «los extremos» políticos ${ }^{46}$.

El dirigismo de la cultura política progresista, claramente perceptible incluso en el discurso de los diputados más proclives a la ampliación generosa del derecho electoral, no era sino una de las facetas del más general elitismo que marcó la concepción de la representación política del conjunto del liberalismo español. La autovaloración como dirigentes naturales de la comunidad no sólo caracterizó a los ideólogos del moderantismo, que la argumentaron teóricamente con la capacidad económica y cultural, sino que definió también al progresismo, con su imaginario de «patricios» que representarían a la nación en relación a su superioridad esencial y a su capacidad para armonizar intereses fragmentados en bien del común ${ }^{47}$. Debido a ello, la figura del elegible quedó diseñada en el modelo de representación progresista con rasgos distintos a los que debían caracterizar al elector: dándose por supuesta la independencia del elegible, el progresismo consideró innecesario el requisito de una renta mínima que garantizara su autonomía, y tipificó al representante parlamentario con virtudes enraizadas en el ideal meritocrático del liberalismo gaditano, de índole básicamente moral ${ }^{48}$. El esfuerzo de modernización de acuerdo a los cánones del liberalismo posrevolucionario se dirigió pues básicamente a la figura del elector.

Sin embargo, este elitismo fue compatible en el progresismo con una visión generalmente positiva de la participación política de la sociedad, que se consideraba encauzable a través de procedimientos institucionalizados que ordenarían la movilización. El sistema electoral jugaba en este sentido un papel protagonista, pues además de ser un elemento teórico nuclear para el gobierno representativo, podía y debía servir también de forma eminentemente práctica para organizar buena parte de las manifestaciones políticas de la sociedad. En este último sentido, y aunque en los sectores más conservadores del partido iban imponiéndose versiones menos optimistas sobre la movilización social, según ésta aumentaba efectivamente a partir de la década de 1850, el núcleo central del progresismo defendió la bondad política de la «agitación» de la sociedad. Ya con anterioridad a su llegada al poder en 1854, Madoz realizó una interpelación al gobierno «sobre el derecho que puedan tener los electores de todos los partidos para reunirse a fin de tratar y convenir los medios de obtener el triunfo electoral». Esta iniciativa, rechazada

46 Expresiones contenidas en el Dictamen de la Comisión encargada de las Bases Electorales aprobadas en 1856, DSC, 10-12-1855, p. 8.971.

47 Véase Romeo Mateo, $M^{\mathrm{a}}$.C.: «Patricios y nación: los valores de la política liberal en España a mediados del siglo XIX», en Mélanges de la Casa de Velázquez (Madrid) 65-1, (2005), pp. 119-141 y Romeo MateO, $\mathrm{M}^{\mathrm{a}}$.C.: «Joaquín Maria López, un tribuno republicano en el liberalismo», en MOREno LúZÓn, J. (ed.): Progresistas, Madrid, 2006, pp. 59-98.

48 El no exigir renta al elegible es considerado como parte de los «buenos principios y tradiciones del partido liberal», y «consecuencia lógica de la revolución de julio [de 1854]», Dictamen de la Comisión de Bases Electorales, DSC, 10-12-1855, p. 8.972. 
entonces - 1848 - por el gobierno moderado, fue luego incorporada por el partido progresista en su Proyecto de Ley Electoral de 1856, al legalizar la competencia electoral de partidos ${ }^{49}$.

Por ello, los diputados progresistas que se encargaron de la legislación electoral dedicaron un amplio esfuerzo a determinar los procedimientos a través de los cuales la participación de la sociedad podría traducirse adecuadamente en la obtención de una representación nacional. En la materialización del voto, los parlamentarios progresistas priorizaron dos líneas de reflexión articuladas en torno a la clave de la «autenticidad». En primer lugar, los aspectos más externos de la misma, es decir, los procedimientos que habían de seguirse y las garantías que debían establecerse para asegurar la independencia y la libertad del acto electoral; y en segundo pero predominante lugar, la determinación del mismo sentido de autenticidad, es decir, qué debía ser objeto de representación. La primera cuestión ocupó muchas horas del debate parlamentario y concitó el esfuerzo de diputados progresistas que reiteraron enmiendas, proposiciones y, cuando pudieron, proyectos de ley que se centraban en la búsqueda de «limpieza» electoral. Junto a propuestas para formar comisiones parlamentarias investigadoras de escándalos o para determinar la responsabilidad de los funcionarios públicos en la manipulación de los resultados, la iniciativa progresista en esta materia insistió especialmente en los defectos de una estructura administrativa centralizada de autoría moderada que, en su opinión y en relación a su propio modelo de organización municipal y provincial, perjudicaba especialmente la autenticidad de las consultas electorales al facilitar de mil maneras la presión del gobierno convocante. Así, la proposición de ley de Madoz en 1848 en la que se denunciaba la manipulación electoral que el gobierno ejercía a través de la figura del jefe político — que remataba su capacidad perturbadora de la autenticidad electoral con el gesto final de «mandar a última hora hornadas de electores donde lo necesitan para vencer a los contrarios»-, ejemplificaría una reflexión en la que participaron otros diputados progresistas ${ }^{50}$.

Sin tanto protagonismo formal pero con mayor importancia aún, la determinación de qué sectores o intereses sociales debían ser representados en consideración de su vinculación con la «voluntad nacional», atrajo también la atención de varias iniciativas parlamentarias dirigidas a definir el concepto progresista de «autenticidad». Coincidiendo con otras fuerzas políticas, este debate se produjo

49 Madoz, DSC 18-12-1848, p.501. En el Capítulo V del Proyecto de Ley de 1856 se arbitraron formas de competencia partidista preelectoral (reuniones y propaganda) por primera vez en la legislación electoral española. DSC, 8-6-1856, pp. 13.057-13.067. En algunos diputados la visión positiva de la movilización política y de su expresión electoral llegó a la defensa de generalizar el derecho al voto a la Milicia Nacional, considerada el «sostén de las instituciones»: así lo afirmaba Calvo Asensio, que subrayaba la ironía de que a los «honrados ciudadanos» «no se les exigía la papeleta de la cuota de contribución» para jugarse la vida en las barricadas pero sí a la hora de votar. DSC, 1-2-1856, p. 10.467.

so DSC, 17-2-1848, p. 1.220 . 
en términos de cuáles debían de ser los «intereses legítimos» que podían aspirar a tener una «influencia moral» en la gobernación del país a través de su representación electoral. Y al igual que moderados y unionistas, los progresistas oscilaron entre la legitimidad del ejecutivo concebido como una especie de poder civilizador, garante de un interés verdaderamente global frente a los intereses fragmentarios que, de diferente forma, habría detrás de los partidos o de las demandas locales, y la legitimidad de estos otros intereses que, aunque parciales, se basarían en influencias reales y garantizarían un freno al poder artificial e invasor del gobierno central. Las opciones de los diputados progresistas en este dilema dependieron de sus distintas condiciones biográficas antes que de preferencias ideológicas: si notables provinciales como Navarro o Bueno defendieron la autenticidad y la legitimidad del diputado que, sobre la base de sus propiedades y raíces en el distrito representaba las necesidades de sus «comitentes», otros diputados progresistas más vinculados con la esfera política madrileña como ámbito de toma de decisiones en un Estado de diseño centralizado o con responsabilidades de gobierno, llegaron a reconocer la necesidad de neutralizar las influencias locales y de considerar al ejecutivo como garantía de una voluntad unitariamente nacional. En este sentido, Escosura como Ministro de la Gobernación pidió a sus compañeros de filas, en el debate sobre la Ley Electoral de 1856, que se liberaran de la persistente idea, consecuencia nefasta de siglos de despotismo, de que «el Gobierno es un enemigo de la sociedad», y le concedieran el beneficio de considerar que se esforzaba por dotar de una estructura constitucional al país ${ }^{51}$.

Las versiones sobre los intereses legítimos representables variaron pues según circunstancias individuales, pero su suma caracterizó al conjunto del progresismo con un discurso doblemente crítico, dirigido contra la injerencia del gobierno central pero también contra la influencia de las elites locales. A pesar de indicaciones como la de Escosura, la desconfianza hacia el gobierno y la denuncia de la ilegitimidad de su influencia, fue generalizada en un partido que vivió mayoritariamente en la oposición y con escasas expectativas de acceso al poder. Aún en 1870 y a pesar de la nueva posición lograda tras la revolución, se puede constatar esta herencia en el discurso demócrata de antiguos progresistas como Godínez. Sin duda, el liberalismo conservador pudo permitirse un discurso más convencido sobre la autoridad moral del gobierno. Como también pudo defender con más coherencia la influencia de los poderes locales, desde la afirmación de que los intereses representados por estos notables eran decididamente legítimos y no debían de ser desconsiderados. El progresismo, por el contrario, elaboró un discurso crítico sobre el «caciquismo», definido como abuso de poder de los ricos de cada localidad con una lectura política de manipulación electoral, que negaba legitimidad a la influencia de las notabilidades

51 Discusión de la Base 9a, sobre incompatibilidades parlamentarias, DSC, 14-12-1856. La intervención de Escosura en p. 10.742. 
«de campanario». Ello no obsta para que, en una clara demostración de cómo el discurso y la práctica política quedaban disociados dentro de una cultura política que compartía con el liberalismo conservador una concepción del poder extremadamente elitista, los diputados progresistas que podían utilizar electoralmente sus relaciones clientelares y económicas en aquellas comarcas en las que estaban enraizados, lo hicieran sin considerarlo moralmente cuestionable: casos conocidos como los de Sagasta, Olózaga o Venancio González, son ejemplos del $51 \%$ de diputados progresistas de esta muestra que obtuvieron actas en el Congreso o el Senado desde distritos donde disfrutaron su patrimonio y construyeron sus redes de favor.

El modelo electoral progresista, articulado en torno a la idea de la ampliación ordenada del derecho al voto, dando prioridad a la «autenticidad» en el camino intermedio antes que la urgencia en alcanzar el lejano punto de destino final, fue abandonado con el nuevo giro revolucionario decidido por los líderes del partido ante la creciente exclusión política de la última etapa isabelina. La opción de retomar el lema de la democracia, en consonancia con la alianza conspirativa con este partido, resultó cuando menos forzada y, sin duda, conflictiva, pues el acceso al poder en 1868 se hizo desde un discurso sobre la representación que no era el propio. En realidad, el momento del progresismo había pasado: su propuesta reformista de declarada inspiración inglesa, que pudo tener una importante potencialidad en la autentificación del sistema representativo durante los años cuarenta y cincuenta, había perdido su significado ante las nuevas demandas que condujeron a la revolución del 68.

\section{5. «MEJORAR CONSERVANDO»}

La Unión Liberal tuvo siempre un difícil encaje ideológico. Bajo ese nombre se presentaron candidaturas en las elecciones a Cortes de 1854 , pero no fue hasta su acceso al poder cuando quedó mejor definida. Según Durán de la Rúa, la carencia de dogmas es la clave para explicar su larga perduración en el poder: las grandes cuestiones que habían sido foco de los debates hasta 1858 —equilibrio de poderes Corona-Cortes, representación de todos los intereses, pugna entre gobierno central y gobiernos locales- quedaron marginadas; O'Donnell desarrolló su política como «una serie de acuerdos entre caballeros», siendo Posada Herrera su complemento ideal a través de la distribución de favores y el control de la maquinaria electoral ${ }^{52}$. La diversidad de orígenes que conformó el unionismo podemos verla a través de los diputados seleccionados ${ }^{53}$ : unos llegaron des-

52 DURÁN DE LA RÚA, N.: La Unión Liberal y la modernización de la España isabelina (18541868), Madrid, 1979, pp. 87-103. Centrado en el caso valenciano, véase MARTíNEZ GALLEGO, F.A.: Conservar progresando: la Unión Liberal (1856-1868), Valencia, 2001.

53 Estos son: Antonio Cánovas del Castillo, Manuel Durán y Bas, Sebastián de la Fuente Alcázar, José Gálvez Cañero y Ariza, Vicente Hernández de la Rúa, Miguel María Jalón y Larragoiti (marqués de Torreorgaz), José López Domínguez, Francisco de Pedro Monguilán (barón de Salillas), 
de el grupo puritano de los moderados —Cánovas, Durán, Polo_-, otros procedieron del sector moderado del progresismo — Gálvez Cañero, Hernández de la Rúa, Pedro-, y los menos iniciaron su experiencia política directamente en la Unión Liberal —Fuente Alcázar, López Domínguez-. Si bien todos menos uno - el general López Domínguez - fueron licenciados en Derecho, cabría diferenciar aquellos que desarrollaron una carrera profesional dentro de la magistratura o de la Universidad —Fuente Alcázar, Gálvez Cañero, Hernández de la Rúa, Zorrilla y Durán y Bas- de los diputados que, sustentados por propiedades agrarias, fueron ministros, como Cánovas y Posada ${ }^{54}$.

En todo caso, siguiendo las intervenciones de los unionistas en el Congreso, encontramos en su discurso elementos recurrentes acerca de la representación política. Quizá, la cuestión en torno al cual giraron todas las demás fue el de la «independencia política» de los electores y de los elegidos, condicionada por el papel que desempeñase el ejecutivo. En primer lugar, ¿cómo se definía al electorado? Desde luego, con carácter censitario, aunque el unionismo entendía que el cuerpo electoral debía ampliarse progresivamente. Posada presentó en 1860 un proyecto de ley electoral en cuyo preámbulo señalaba que el disfrute de renta o pago de contribución actuaba como criterio de «capacidad política». El Gobierno consideraba ajustada la cuota de 400 reales fijada por la ley de 1846, pues, gracias al incremento de la riqueza experimentado en España en el transcurso de esos quince años, se iba a duplicar el número de electores. Aumentar la cuota no era pertinente «cuando el espíritu de la época nos empuja hacia otro lado», pero reducirla tampoco ya que "nos acercaría al sufragio universal, incompatible con nuestras instituciones» ${ }^{55}$. Precisamente, apelando a ese «espíritu», Polo proponía bajar la cuota, sin que llegase a significar, eso sí, el sufragio universal: "Aquí las posiciones sociales no marcan las opiniones políticas, ni hay clases medias en peligrosa pugna con las clases proletarias, ni serían más, sino menos, las personas que resolverían las elecciones, si a impulso de mal aplicadas teorías se concedieran hoy a manos llenas los derechos electorales»56. Fue en 1865 cuando la Unión Liberal postuló su máxima apertura al dejar la cuota electoral en 200 reales como respuesta «a la organización social presente». Aunque alguno, como López Domínguez, miraba un poco más le-

José Polo de Bernabé y Borrás, José Posada Herrera y Miguel Zorrilla Ruiz del Árbol.

54 Posada fue catedrático de Ciencia de la Administración en la Universidad de Madrid desde 1843, pero su cursus honorum puede considerarse exclusivamente político. Ideológicamente circuló por el progresismo (1839-1843) y el moderantismo (1844-1857) hasta llegar al unionismo en 1858 y finalizar en el partido liberal con la Restauración. Para Durán de la Rúa, sin embargo, el político asturiano «distaba mucho de ser un ideólogo; es más, las ideas motivaban en él su más profundo desprecio». DURÁN DE LA RÚA, N.: Op. Cit., p. 93. No resulta extraño que, si bien sólo publicó Lecciones de Administración (1843), fuese miembro de las comisiones que redactaron las Constituciones de 1869 y 1876.

55 DSC, 28-6-1860, Ap. $1^{\circ}$ al no 26, pp. 643-651.

56 Archivo del Congreso de los Diputados (ACD), Serie General, leg. 114-6, 3-5-1861. 
jos. Partiendo de lo existente, era necesario «mejorarlo en sentido liberal», pues, aunque la sociedad española no estaba suficientemente ilustrada, "vamos caminando con paso firme por el camino del progreso: no retrocedamos y perfeccionaremos todo el sistema» ${ }^{57}$.

Tan importante como la independencia del elector era la del elegido. La clave residía entonces en la condición del diputado y la función política que debía desempeñar en el Congreso, lo que se sustanciaba en el grado de compatibilidad del cargo. En este punto, conviene llamar la atención sobre la posición de aquellos unionistas situados en la esfera del ejecutivo. Cánovas, Posada y López Domínguez postularon una reducida incompatibilidad para el diputado, como se fijaba en el Proyecto de Ley electoral de 1860 y en la Ley de Incompatibilidades de 1864, que permitía la compatibilidad a todos los altos cargos residentes en Madrid, a los no residentes con un sueldo superior a los 30.000 reales, así como a los militares de alta graduación. Quedaba así garantizada, según Cánovas, una amplia libertad de voto para el elector. Pero, además, si se prohibía la presencia de ciertos funcionarios cualificados en el Parlamento, no sólo se restringía el acceso «a lo más activo de la clase media», sino que se cercenaba el fundamento de los partidos políticos, que eran, para el estadista malagueño, organizaciones esencialmente parlamentarias ${ }^{58}$. En cambio, Polo creía que las incompatibilidades debían ser más amplias, aunque no absolutas, pues si así fuese «impediría con grave daño del Estado que el Congreso y sus hombres notables se identificaran con la Administración pública, y cuando llegara al poder un partido nuevo le harían casi imposible llevar a ella su acción». Proponía, pues, que formasen parte del Congreso un reducido número de funcionarios - unos 20 o 25 altos cargos-, para que no influyesen «indebidamente» en las decisiones de la Cámara 59 .

La gran paradoja del discurso unionista vino por la distancia que estableció entre sus fórmulas teóricas para garantizar la pureza del régimen representativo y la práctica injerencia del Gobierno. El partido de O'Donnell defendió que el sistema electoral debía ser «objeto de transacción» ${ }^{60}$ porque resultaba esencial llegar a un consenso para dar estabilidad al régimen liberal. Y de ello es muestra la Ley Electoral de 1865 que, con la rebaja del censo a los niveles propuestos por los progresistas años antes, el establecimiento de distritos grandes con modo de escrutinio plurinominal, y la asunción de la Ley de 1864 sobre

57 Respectivamente, DSC, 3-7-1865, pp. 3.000-3.001, y 23-3-1866, p. 745.

58 DSC, 30-4-1864, pp. 1.795-1.798.

59 ACD, Serie General, leg. 114-6, 3-5-1861. De este modo, se daba representación a «la clase de empleados, que vendrían a representar los mejores en el sentido parlamentario, los que se consagran completamente a la política». DSC, 25-4-1864, pp. 1.683-1.684.

60 DSC, Cánovas, 22-3-1864, p. 1.248. El carácter transaccional era lo que mejor definía a la corriente puritana que había nutrido el unionismo. GómEz OCHOA, F.: «El conservadurismo canovista y los orígenes de la Restauración: la formación de un conservadurismo moderno", en SUÁREZ Cortina, M. (Ed.): La Restauración, entre el liberalismo y la democracia, Madrid, 1997, pp. 109-155. 
delitos electorales, establecía un amplio campo de juego para los comicios. Pero no es menos cierto que, desde el primer momento, los gobiernos de la Unión Liberal sostuvieron la intervención «civilizadora» del ejecutivo. Como afirmó Posada: «Su señoría [Aparisi] cree que las elecciones serían libres no existiendo ninguna clase de influencia del Gobierno, y yo creo que no lo serían, yo creo que serían menos libres que en la actualidad; creo que en lugar de la influencia oficial habría otras influencias locales mucho más opresoras, mucho más contrarias al bien público». El político asturiano no desconocía, seguramente, que muchos de los diputados unionistas —un 66\% de nuestra muestra- obtenían su escaño en provincias donde poseían tierras y vínculos familiares, pero ello no era óbice para ponderar la influencia de un «Gobierno central responsable», sometido a control parlamentario y de la opinión pública, sobre las de «agentes oscuros sin responsabilidad política» ${ }^{61}$. Al igual que moderados y progresistas, los unionistas plantearon la cuestión de las «legítimas influencias» en la tensión entre el poder central y los poderes locales, pero considerando lícito articular la periferia bajo la tutela de Madrid.

Sin embargo, algunas voces críticas dentro del unionismo opinaron que sin «verdad electoral» no existía gobierno representativo, postulando, como mejor garantía, la regeneración de los partidos. Un primer indicador de ello es que se hablaba de "partido conservador» para referirse a la Unión Liberal, desvinculando aquel término de su inicial identificación con el moderantismo, sobre todo por lo que había significado de exclusivismo político. Polo afirmó que debía ser «un partido parlamentario» ${ }^{62}$, mientras que Durán y Bas propuso «la unión de los hombres constitucionales, para llegar a la reconstitución necesaria, indispensable del partido conservador y del partido progresista» ${ }^{63}$. En la misma línea encaja la exigencia de la incompatibilidad absoluta del cargo de diputado por parte Hernández de la Rúa, Durán y Bas y Pedro. El primero estimaba que, con la Ley de Cánovas de 1864, podían ser diputados cerca de 600 funcionarios y, contando a los militares, «aquí puede formarse con mucha facilidad un consejo de guerra» ${ }^{64}$. Para Durán y Bas, la existencia de diputados funcionarios favorecía la intervención del Gobierno en los comicios, pues éste hacía todo lo posible para que sus candidatos obtuviesen el acta, dando lugar a lo

61 DSC, $22-3-1859$, p. 2.065.

62 DSC, 26-4-1864, pp. 1.694-1.695. Polo fue el primero en proponer auténticas garantías para el secreto del voto como la utilización del sobre para la papeleta y de la cabina electoral. ACD, Serie General, leg. 114-6, 3-5-1861. En 1875 publicó Indicaciones sobre la ley electoral, donde expuso sus principales ideas acerca del régimen representativo.

63 DSC, 28-4-1864, p. 1.749. Desde 1853, buena parte de los antiguos moderados catalanes rechazaron este calificativo para llamarse en exclusiva «conservadores». RIQUER I PERMANYER, B. de: $O p$. Cit. p. 48. Durán, abogado y jurista, colaborador en El Bien Público y Diario de Barcelona, fue un prolífico publicista. Destacamos: El individualismo y el Derecho (1852), Estudios Políticos y Económicos (1856), Memoria acerca de las instituciones del Derecho Civil de Cataluña (1883), Estudios Jurídicos (1888).

64 DSC, 6-5-1864, p. 1.854. 
que el político catalán calificaba como «una gran epidemia moral» ${ }^{65}$. En el fondo, estos diputados defendían la alternancia y el pacto entre partidos, con su correlato del equilibrio entre «legítimas influencias», desde una concepción que reforzaba el papel de las organizaciones políticas pero no alteraba el papel secundario adjudicado a los electores. Tal convicción se vería reforzada por la percepción del sufragio universal que los políticos conservadores tuvieron durante el Sexenio.

\section{6. «LAS PEORES CORTES SON MEJORES QUE LA MEJOR CORTE»}

A lo largo de su recorrido por el ochocientos, la cultura política demócratarepublicana presentó diversos perfiles. El denominado demoliberalismo fue uno de ellos, conformando un imaginario social donde intentaba definir la preeminencia entre el individuo y el todo social, estereotipado como "pueblo-nación». Éste era el objeto a democratizar, y, según Miguel González, lo prioritario para dicha corriente fue crear un régimen político democrático, centrándose en movilizar a las clases medias contrarias al sistema centralista y oligárquico ${ }^{66}$. Dentro del demoliberalismo podemos situar a 8 diputados de nuestra muestra ${ }^{67}$. Aunque pertenecientes a generaciones distintas, todos coincidieron en las primeras Cortes del Sexenio, habiéndose destacado los veteranos Orense y Sorní por un marcado perfil conspirador. Estos, como Martos y Godínez de Paz, desarrollaron una activa labor en periódicos afines como La Democracia, La Discusión y La Vanguardia y, mientras Orense sobresalió como publicista político, Martos y Sorní, abogados de profesión, escribieron sobre legislación y jurisprudencia ${ }^{68}$.

Desde el prisma demoliberal encaja la caracterización que los diputados citados hicieron sobre las figuras del elector y del elegible. Su principal bandera

65 Durán y Bas presentó una enmienda al Proyecto de Ley de Cánovas. DSC, 25-4-1864, Ap. $1^{\circ}$ al $n^{\circ} 110$. La cita en DSC, 23-3-1866, p. 756. Pedro planteó una enmienda al Proyecto de Ley de 1870. DSC, 28-4-1870, Ap. $1^{\circ}$ al no 268.

66 Duarte, A., y Gabriel, P.: «¿Una sola cultura política republicana en la España ochocentista?», en Ayer (Madrid) 39 (2000), pp. 11-34. Miguel GonZÁLEZ, R.: «Las culturas políticas del republicanismo histórico español», en Ayer (Madrid) 53 (2004), pp. 207-236, p. 228.

${ }_{67}$ Se trata de Ángel Carvajal Fernández de Córdoba (marqués de Sardoal), Rafael Cervera Royo, Rafael Coronel Ortiz, Carlos Godínez de Paz, Cristino Martos Balbi, José María Orense Milá de Aragón (marqués de Albaida), Ignacio Rojo Arias y José Cristóbal Sorní Grau. Este último defendía las posiciones sociales más radicales, y fue uno de los 19 diputados que votó contra la monarquía en las Cortes del Bienio.

68 Orense fue autor de opúsculos como: ¿Qué hará en el poder el partido progresista? (1847), La democracia tal cual es (1862), Treinta años de gobierno representativo en España (1863) o Ventajas de la república federal (1870). Martos publicó La Revolución de 1854 (1854); Carvajal escribió Establecimiento definitivo de las instituciones inglesas, petición de derechos, Habeas corpus y bill de derechos (1867); Coronel fue autor de Breves nociones de historia de España (1862) y de una reseña sobre Constituciones vigentes de los principales Estados de Europa y América (1864). 
fue la defensa del sufragio universal masculino. Apelando al mito de la Constitución de 1812, Orense afirmaba que, como derecho inherente al hombre, era una «tiranía» privarle de él, y no tenía ningún sentido considerarlo un derecho político, ya que no cabía distinguir derechos civiles y derechos políticos, como hacían los progresistas ${ }^{69}$. La concesión del voto a los pobres, tendría, además, efectos positivos, pues los representantes, por interés o por filantropía, legislarían en su favor, estableciendo así una relación directa entre situación económica y representación política ${ }^{70}$. Y, frente a la crítica de que las personas sin recursos serían fácilmente manipulables, Orense esgrimía que «de todas maneras, ese amo que quiere el voto del pastor para él o para sus amigos, tendrá que quitarse el sombrero para pedirle ese favor, cuando de otro modo no tiene que contar con él para nada» ${ }^{71}$. Con ello, el político cántabro dejaba muy clara la relación clientelar que se establecía entre electores y candidatos, dando legitimidad al poder político emanado de los vínculos socioeconómicos. La propia experiencia de algunos demócratas avalaba esta posición. En las elecciones de 1854, Orense, Ordax y García Ruiz, entre otros, fueron elegidos en provincias donde radicaban muchas de sus propiedades ${ }^{72}$.

Conviene matizar, por otra parte, la posición moderada y gradual que planteaban muchos demócratas para la asunción del sufragio universal. Según Orense, vista la experiencia de Francia tras la revolución de 1848, y en consonancia con el modelo inglés, la democracia no era algo que se conquistaba en «un momento de efervescencia popular», sino que era fruto de «instituciones dadas y concebidas quieta y pacíficamente» ${ }^{73}$. Un actitud gradualista que se plasmó muy bien en la alianza con los progresistas durante el Bienio. Con anterioridad, Orense había defendido el derecho de voto para quienes tuviesen «casa abierta» ${ }^{74}$, utilizando este criterio de inspiración británica como primer elemento para la ampliación del sufragio, y durante el debate del Proyecto de Ley de 1856 sostuvo un enmienda donde proponía la rebaja progresiva de la cuota, de forma que el derecho al voto sería universal transcurridos doce años. En la misma línea, Sorní presentó una enmienda para fijar la cuota máxima en 110 reales como expresión de «los principios de la revolución de julio». El texto de 1856 establecía, además, la capacidad como requisito para votar, y Orense propuso ampliarla con la concesión del derecho a los milicianos nacionales, los soldados y los padres de los que estuviesen sirviendo en el ejército. El voto para

69 DSC, 22-1-1856, p. 10.064 y 31-1-1856, p. 10.424.

70 Laguna Platero, A.: «José María Orense, ideólogo del partido demócrata español» en Hispania (Madrid) 44 (1984), pp. 343-368, esp. pp. 354-360.

71 DSC, 22-1-1856, p. 10.066.

72 Castro Alfín, D.: «Unidos en la adversidad, unidos en la discordia: el Partido Demócrata, 1849-1868», en TOWNSON, N.(ed.): El republicanismo en España (1830-1877), Madrid, 1994, pp.59-85, p.68.

73 DSC, 31-1-1856, p. 10.424.

74 DSC, 6-2-1846, pp. 571-574. 
la Milicia Nacional era la correspondencia lógica por su apoyo «a la situación», mientras que en el caso del Ejército se trataba de una cuestión de «justicia social», en pago de la «contribución de sangre» de los soldados. Una exigencia completada tras la revolución de 1868, cuando Cervera solicitó la reducción de la edad electoral de 25 a 20 años, lamentando que, aunque a los 21 años muchos jóvenes poseían título profesional y podían figurar en la vida pública, carecían del derecho electoral ${ }^{75}$.

Si de los electores pasamos a los elegibles, la concepción que tenía Orense de los representantes políticos era, como la de los demás liberales, elitista. En 1846 había presentado, junto con algunos diputados moderados, una enmienda a la ley que fijaba una renta de 20.000 reales como requisito para aquellos que aspirasen al escaño, y durante el Bienio aludió en varias ocasiones a Montesquieu al señalar que la tendencia del pueblo era elegir a los más ricos y a los más preparados ${ }^{76}$. Estos últimos eran, en muchos casos, funcionarios de alto nivel — catedrático, ingeniero, general—, y se pedía para ellos la compatibilidad del cargo de diputado. Martos presentó, en ese sentido, una enmienda al Proyecto de Ley electoral de 1870, al afirmar que la incompatibilidad absoluta sólo era posible si los diputados percibían dietas, como en Francia, Portugal y Bélgica. Pero España carecía de «aristocracia política» y, ante la impopularidad de las dietas, sólo era plausible un sistema de cierta compatibilidad; de lo contrario, no llegarían al Parlamento personas como Sagasta, Echegaray, Prim, Moret o Castelar ${ }^{77}$. El tema de la incompatibilidad no sólo se insertaba en la discusión sobre aptitud y capacidad de los elegibles, sino que estuvo estrechamente relacionado, como vieron las otras formaciones políticas, con el de la representación de intereses «legítimos». La desconfianza demócrata hacia el Gobierno y la denuncia de la ilegitimidad de su influencia la expresaba claramente Godínez de Paz, presidente de la Comisión que redactó el proyecto de 1870: «Yo he considerado siempre que la influencia que se ejerce sobre los electores ilustrándolos y determinándolos a votar tal o cual candidato, ó a favor de tal ó cual idea política, esa influencia es más legítima que la que ejercen las autoridades desde el Ministerio de la Gobernación». Quizá por ello, su compañero Coronel propuso una enmienda por la que los candidatos a diputado pudieran recibir votos en los distritos donde fuesen alcaldes ${ }^{78}$. La proximidad en-

75 Orense, DSC, 7-2-1856, pp. 10.548-10.550. Sorní, DSC, 1-2-1856, pp. 10.454-10.458. Cervera, DSC, 6-4-1870, pp. 7.153-7.156.

76 DSC, 4-2-1846, p. 537 y 22-1-1856, pp. 10.064-10.066. En 1848, incluso el utopista Sixto Cámara afirmaba: «el gobierno no es la acción ciega y desordenada de los incapaces, sino la acción inteligente y utilitaria de los capaces...». Cit. por FERNÁNDEZ SEBASTIÁN, J.: «Democracia», en FernándeZ Sebastián, J. y Fuentes, J.F. (eds.): Diccionario político y social del siglo XIX español, Madrid, 2002, p. 223.

77 DSC, 5-4-1870, p. 7.139.

78 Respectivamente, DSC, 22-4-1870, pp. 7.344-7.346, y 1-4-1870, Ap. $2^{\circ}$ al no 253. Por su parte, Rojo defendió una enmienda a favor de las elecciones por provincias por considerar que este modelo dificultaba la influencia del ejecutivo. DSC, 21-4-1870, Ap. $2^{\circ}$ al no 262. 
tre elector y elegible devenía así un principio básico en la concepción demócrata y republicana de la representación política. En ella convergía la defensa de una cierta autonomía de la Administración local, con una suerte de «educación electoral» de los ciudadanos, según la cual estos votarían libremente a los candidatos.

\section{7. «CORTES A LA ESPAÑOLA, NO A LA FRANCESA»}

En el hemiciclo alzaron también su voz los neocatólicos y los tradicionalistas, críticos con el sistema representativo. Dentro de nuestra muestra, encontramos a Antonio Aparisi y Guijarro y a Ramón Ortiz de Zárate. Pertenecientes a la misma generación, ambos ejercieron la abogacía y destacaron como periodistas, a lo que Ortiz unió su condición de gran propietario en Álava. Los dos fueron, además, prolíficos publicistas y convergieron en el carlismo a raíz de la revolución de $1868^{79}$.

Tras la estela del pensamiento de Balmes, Aparisi situó la religión católica en el centro de sus argumentaciones, al considerarla la base del orden social y la fiadora de la libertad ${ }^{80}$. A partir de aquí, el político valenciano era contrario al sufragio universal "porque es una doctrina que se hace derivar de un principio falso, de la igualdad de todos los hombres en punto a intervenir en la gobernación del país; Dios no ha querido esta igualdad; para gobernar o influir en la gobernación del Estado nacen muy pocos; para ser gobernados nacen casi todos» ${ }^{81}$. Rechazaba el régimen liberal porque encarnaba "el espíritu francés, escéptico y burlón, materialista y revolucionario, que jamás supo dar libertad a su patria», pues lo que Francia enseñaba era que si en el sistema parlamentario "prevalece la idea progresista, es una República vergonzante; si la idea moderada, es un absolutismo disfrazado ${ }^{82}$. Y el parlamentarismo que Francia había enseñado a España no era verdaderamente representativo debido a la corrupción en las elecciones, motivada fundamentalmente por la injerencia del Gobierno. Esto explica la proposición de ley que Aparisi presentó en 1859, como una enmienda a la ley electoral de 1846, centrada sobre todo en la actuación

79 Aparisi colaboró en los diarios madrileños La Esperanza y La Estrella, fundó El Pensamiento de Valencia y escribió, entre otras: Oda a la amnistía que ha concedido S. M. la Reina nuestra señora (1833); España en África: oda (1860); La cuestión dinástica (1869). Ortiz fue redactor de El Semanario Católico Vasconavarro y director de La Gaceta del Norte, y publicó: Análisis histórico-crítico de la legislación española (1844); Jamás los romanos conquistaron completamente a los vascongados (1848); Observaciones al proyecto de Código Civil (1852); Compendio foral de la provincia de Álava (1858). Ambos obtuvieron escaño en las elecciones generales de 1869. URIGÜEN, B.: Orígenes y evolución de la derecha española: el neocatolicismo, Madrid, 1986, pp. 314-329.

80 Romeo MateO, $\mathbf{M}^{\mathrm{a}}$.C.: «Política católica...»

81 DSC, 4-7-1865, p. 3.019.

82 DSC, 22-3-1859, pp. 2.057-2.058. 
de los gobernadores civiles. En la misma línea, Ortiz de Zárate, con experiencia en la administración municipal y provincial, también mostró su preocupación por «moralizar las elecciones» durante el debate del Proyecto de Ley de sanción de los delitos electorales de $1864^{83}$.

El modelo representativo que ambos políticos sostenían tenía un carácter claramente corporativo, y Aparisi, en concreto, defendía una reforma de la Constitución para acercarla a la «constitución histórica», fundamentada en la religión y la monarquía. Las Cortes trataban sobre impuestos, dirigían peticiones e intervenían en la formación de las leyes, pero éstas eran propuestas y aprobadas por el rey ${ }^{84}$. La limitación del poder de las Cortes tenía su correlato con la superación en su seno de las diferencias políticas, de forma que Aparisi defendía, frente a la Unión Liberal, la «Unión Española», que agruparía a los católicos monárquicos opuestos al sistema liberal ${ }^{85}$. Paradójicamente, Aparisi participó activamente del «juego» parlamentario. En 1843, señalaba que la acción del gobierno debía asegurarse mediante la elección de diputados católicos, recordando que ir a votar no era un derecho sino una obligación de conciencia $^{86}$. Derrotado en 1857 en un distrito de la capital valenciana donde se presentó candidato por primera vez, obtuvo el escaño al año siguiente, gracias sobre todo a su reconocida actividad periodística. Una vez en el Congreso, se jactó de la limpieza de su acta, comprometiéndose con el programa que sus electores le habían encomendado: abogar por la reducción de los gastos del Estado y defender la justicia para todos ${ }^{87}$. El diputado tenía que ser una persona políticamente independiente, y, en este sentido, Aparisi entendía que dicha independencia no era posible si los representantes gozaban de un empleo del Gobierno, por lo que defendió la incompatibilidad absoluta. Los elegibles debían ser solventes, pues de lo contrario el distrito tenía que asegurar al diputado una "pensión para su subsistencia» ${ }^{88}$. La estrecha vinculación territorial del diputado con el distrito traslucía una defensa del mandato imperativo y el peso de la «legítima influencia» local frente al centralismo de Madrid.

83 DSC, 19-2-1859, Ap. $4^{\circ}$ al no 57 y DSC, 17-3-1864, p. 1.184, respectivamente.

84 Los diputados accederían al hemiciclo por tres vías: 100 serían elegidos por los padres de familia por medio de compromisarios; otros 100 por los propietarios que pagasen más de 6.000 reales de contribución y los comerciantes de las dos primeras cuotas, también de forma indirecta; el rey designaría los 100 restantes entre grandes de España y personalidades propuestas por los tribunales supremos, universidades y sociedades de amigos del país. APARISI y GuIJARro, A.: Obras completas, 5 vols., Madrid, 1873-1877, IV, pp. 288-291.

85 DSC, 22-3-1859, p. 2.057 y 23-3-1859, p. 2.092.

86 Romeo Mateo, M ${ }^{\mathrm{a}}$.C.: «Política católica...», pp. 150-151.

87 VillacorTa, J.L.: Op. Cit., p. 53.

88 DSC, 19-2-1859, Apéndice $4^{\circ}$ al no 57. Aparisi y Guijarro, A.: Op. Cit., p. 291. 


\section{CONSIDERACIONES FINALES.}

Es evidente que una completa reconstrucción de los conceptos de representación política manejados por el liberalismo español durante las décadas centrales del siglo XIX exige mayor multiplicidad de fuentes y de perspectivas que la heterodoxamente prosopográfica, centrada en el debate parlamentario, que aquí hemos empleado. Se trata sin duda de un trabajo complejo que requiere, además del análisis del discurso parlamentario, la consulta de material hemerográfico y ensayístico de muy diverso tipo.

Sin embargo, esta propuesta prosopográfica de aproximación a la idea de la representación política nos parece productiva desde el momento en que permite avanzar consideraciones en un doble sentido. En primer lugar, nos proporciona nueva información sobre el perfil generacional, formativo y ocupacional de un grupo de diputados que representa a uno de los segmentos más activos de la clase política formada con el régimen liberal —a la vez que conformadora del mismo- . En este sentido, nos resulta particularmente sugerente la imagen de relativa juventud y renovación generacional que esta muestra nos obliga a considerar, frente a aquellas tesis que recalcan una fuerte continuidad por encima del minimizado corte del sexenio democrático. De cara a nuestro objeto de estudio, las conclusiones sobre el perfil socio-profesional de los artífices de la legislación electoral pueden resultar especialmente interesantes, además de confirmar la pertinencia del enfoque prosopográfico para una aproximación a la teoría del gobierno representativo construida por el liberalismo español, pues revelan hasta que punto los posicionamientos doctrinales estuvieron dirigidos por las circunstancias biográficas individuales. El grupo de diputados sobre los que hemos trabajado indica con meridiana claridad que la condición de propietario-rentista constituía el fundamento material más generalizado de la clase política de la época, lo que no extrañará a nadie y menos si se tiene en cuenta que la misma legislación electoral condicionó con altos requisitos económicos la figura del elegible durante buena parte del siglo XIX. Pero también resulta evidente que en la esfera pública del liberalismo se estaban empezando a abrir puertas para quienes carecían de una plataforma de este tipo, y, así, el ejercicio - libre o funcionarizado - de profesiones liberales — relacionadas mayoritariamente con la formación jurídica- por parte de diputados que no eran además necesariamente propietarios (aunque, con frecuencia, acabasen siéndolo) nos habla de una incipiente modernización de la figura del parlamentario en cuanto a su extracción social, que no llegaría a culminar debido al firme arraigo en la cultura política de la época del rechazo a las dietas. En nuestra opinión, no sólo el Parlamento se abría a la presencia de una posible «burguesía de educación», sino que el protagonismo de los sujetos políticos se estaba decantando del «diputado-propietario» hacia el «diputado-abogado», según sugiere la gestión de debates como éste que nos ha interesado sobre la legislación electoral.

En este sentido, una de las reflexiones obligadas de este trabajo se refiere al tipo de dedicación a la política que caracterizó al grupo que dirigió la elabora- 
ción de las normas electorales y su reforma. Se trata de una atención intensa y extensa, que, si no conviene calificar de "profesional» por el equívoco que implicaría respecto a las fuentes de sustento material de muchos de estos diputados, no cabe duda de que resulta la ocupación principal o privilegiada de buena parte de ellos. Una ocupación sobre la cual dirigieron, además, una mirada reflexiva que incorporó la consideración de cuáles debían de ser la naturaleza y las funciones del representante de la nación, porque su aporte intelectual y político no quedó únicamente vertido en los discursos parlamentarios y recogido en el Diario de Sesiones del Congreso (el lugar por excelencia para conocer «la marcha de las ideas» según supo apreciar Orense). Junto a su protagonismo en la gestión del debate parlamentario, hay que tener en cuenta también su intensa actividad publicística, y, así, además de la frecuente vinculación al mundo del periodismo, la prosopografía de este grupo muestra una amplia y escasamente conocida labor de escritura de folletos, ensayos, discursos académicos y conferencias, que evidencian la preocupación de estos diputados por dotar a su actividad política de la hondura de una reflexión teórica (algo que, por otra parte - pensemos en los abundantes catedráticos incluidos en la muestra-, era para muchos de ellos su modus operandi profesional habitual). Su protagonismo parlamentario quedaría pues amplificado en su repercusión pública por la caja de resonancia que en esta época significaban las academias, los ateneos y las sociedades de diverso tipo, por un lado, y la actividad periodística y publicística por otro.

Un segundo grupo de conclusiones se refiere expresamente a los conceptos de representación política construidos por el liberalismo histórico español, si bien, en esta línea, nuestra aportación pretende solamente apuntar algunas ideas que deberán ser más cumplidamente desarrolladas en trabajos posteriores. Dada la variedad y frecuencia de las iniciativas parlamentarias relacionadas con la elaboración y la reforma de la legislación electoral, no cabe duda de que la clase política española se interesó por la idea de la representación, y de que, bajo la consideración de que se trataba de un importante elemento vertebrador del nuevo sistema de gobierno - junto con las leyes municipal-provincial y de imprenta-, se esforzó en un debate que se estaba desarrollando en paralelo en otros países europeos. La preocupación intelectual y política en torno a la representación no se materializó sin embargo en una elaboración teórica y ensayística como la desplegada en Francia o, aún más tempranamente, en Gran Bretaña, pues, salvo las excepciones mencionadas de Morón y Polo, la producción bibliográfica de los artífices de la legislación electoral española, aunque extensa, se dirigió, como hemos visto, hacia el examen de otros aspectos jurídicos e institucionales del nuevo régimen liberal. Da la impresión de que para los diputados españoles interesados en esta cuestión, la representación se contempló fundamentalmente como un mecanismo práctico de organización del sistema, en cuya reglamentación normativa debían observarse, obviamente, las diversas referencias doctrinales pero también, y sobre todo, las consideraciones sobre los efectos políticos prácticos que se derivarían de una opción legal u otra 
(grado de control gubernamental, alcance dado a la influencia de los poderes locales, beneficios partidistas según se configuraran los distritos).

En parte por ello son constatables entre las distintas fuerzas políticas analizadas importantes coincidencias en temas de reflexión compartidos e, incluso, alguna solución común. Entre esas coincidencias destaca el dilema de las «influencias legítimas», es decir, la determinación de qué intereses-poderesrealidades tenían derecho a ser representadas en el Parlamento. Independientemente de las diferentes opciones partidistas - más proclives los moderados a legitimar el doble derecho del ejecutivo central y los poderes locales, doblemente desconfiados los progresistas respecto a ambas influencias, partidarios de un pacto que anticipaba el canovismo restauracionista los de la Unión Liberal, coincidentes en su inclinación a favor de la autonomía de lo local los extremos del demorepublicanismo y del carlismo - la mayor parte de las fuerzas políticas con representación parlamentaria coincidieron en la consideración de que las elecciones no consistían en ningún caso en libre concurrencia y competencia política —una percepción totalmente extraña en una cultura política elitista y dirigista - sino que eran un «negocio» que debía ser tratado — por aquellos que podían conducirlo en beneficio de algún proyecto común.

No obstante, es igualmente cierto que los conceptos de representación defendidos desde cada partido presentaban opciones distintas que se fundamentaban en - y a la vez querían fundamentar - proyectos políticos diferenciados. La extensión del derecho al voto y el sentido dado a la preocupación de la limpieza electoral consignan, por ejemplo, importantes diferencias entre el liberalismo conservador y el progresista. A pesar de la común limitación censitaria del voto y de la visión compartida de este derecho como una «función», moderados y unionistas difícilmente podían coincidir con progresistas en la visión positiva de la movilización política de la sociedad que llevó a estos últimos a legalizar la competencia electoral partidista de forma novedosa en el Proyecto de Ley de 1856. En otro orden de cosas, la apropiación por parte de neocatólicos y carlistas del lenguaje de la representación no debe inducirnos a identificar su opción de orden y su enrocamiento en torno a la Corona con las posiciones del liberalismo conservador - por más que peregrinajes políticos personales como el de Nocedal colaboren engañosamente a ello-, en una interpretación equívoca que diluiría el visceral antiparlamentarismo de los primeros. La determinación de las diferencias en los discursos políticos en competencia resulta en nuestra opinión una tarea tan importante como la indicación de los recursos comunes.

Una última reflexión derivada de este trabajo constituiría el punto de partida necesario para ambas labores: la perspectiva prosopográfica empleada ayuda a comprender por qué los discursos políticos no son, no pueden ser, unívocos, ni deben estudiarse como universos cerrados. El análisis de las circunstancias biográficas de los diputados incluidos en esta muestra ha revelado cómo sus posicionamientos resultan sustancialmente influidos por circunstancias personales momentáneas o estables: así, las posturas defendidas en la tensión entre 
responsabilidad del ejecutivo-libertad del elector quedaron marcadas con más frecuencia por la cercanía al poder y el ejercicio de cargos ministeriales que por opciones doctrinales, de igual manera que la consideración de la legitimidad del diputado estuvo conflictivamente definida por la situación social y profesional de los mismos parlamentarios que teorizaban sobre esta cuestión. En última instancia, la versatilidad, el cambio, la contradicción e, incluso, la incoherencia, no implican carencia de interés político. En nuestra opinión, no cabe duda de que el liberalismo - e incluso el antiliberalismo- español decimonónico consideró la representación como una de las claves de sustentación del nuevo régimen y se esforzó por articular un discurso y una legislación al efecto según los diferentes proyectos políticos y las opuestas necesidades partidistas. 